\title{
The effect of skin fatty acids on Staphylococcus aureus
}

\author{
Yvonne Neumann $\cdot$ Knut Ohlsen $\cdot$ Stefanie Donat \\ Susanne Engelmann · Harald Kusch • Dirk Albrecht • \\ Michael Cartron · Alexander Hurd · Simon J. Foster
}

Received: 23 July 2014 / Revised: 19 September 2014 / Accepted: 6 October 2014 / Published online: 18 October 2014

(C) The Author(s) 2014. This article is published with open access at Springerlink.com

\begin{abstract}
Staphylococcus aureus is a commensal of the human nose and skin. Human skin fatty acids, in particular cis-6-hexadecenoic acid (C-6-H), have high antistaphylococcal activity and can inhibit virulence determinant production. Here, we show that sub-MIC levels of C-6-H result in induction of increased resistance. The mechanism(s) of C-6-H activity was investigated by combined transcriptome and proteome analyses. Proteome analysis demonstrated a pleiotropic effect of C-6-H on virulence determinant production. In response to C-6-H, transcriptomics revealed altered expression of over 500 genes, involved in many aspects of virulence and cellular physiology. The expression of toxins ( $h l a, h l b$,
\end{abstract}

Communicated by Djamel DRIDER.

Electronic supplementary material The online version of this article (doi:10.1007/s00203-014-1048-1) contains supplementary material, which is available to authorized users.

Y. Neumann · M. Cartron · A. Hurd · S. J. Foster $(\bowtie)$ Department of Molecular Biology and Biotechnology, The Krebs Institute, University of Sheffield, Firth Court, Western Bank, Sheffield S10 2TN, UK

e-mail: s.foster@sheffield.ac.uk

\section{Y. Neumann}

Institute of Molecular and Clinical Immunology, Ottovon-Guericke-University Magdeburg, Leipziger Str. 44, 39120 Magdeburg, Germany

\section{Y. Neumann}

Research Group of Systems-Oriented Immunology and Inflammation Research, Department of Immune Control, Helmholtz Centre for Infection Research, Braunschweig, Germany

K. Ohlsen · S. Donat Institute for Molecular Infection Biology, University of Würzburg, Würzburg, Germany $h \lg B C$ ) was reduced, whereas that of host defence evasion components (cap, sspAB, katA) was increased. In particular, members of the SaeRS regulon had highly reduced expression, and the use of specific mutants revealed that the effect on toxin production is likely mediated via SaeRS.

Keywords S. aureus $\cdot$ Skin fatty acid $\cdot$ C-6-H . Resistance

\section{Introduction}

The Gram-positive bacterium Staphylococcus aureus is able to survive as a commensal organism in the anterior nares and on human skin. A third of the human population are nasal carriers and two-thirds are intermittent carriers, forming a

S. Engelmann $\cdot$ H. Kusch $\cdot$ D. Albrecht

Institute for Microbiology, Ernst-Moritz-Arndt-University,

Greifswald, Germany

S. Engelmann

Institute for Microbiology, Technical University Braunschweig,

Braunschweig, Germany

S. Engelmann

Research Group for Microbial Proteomics, Helmholtz Centre for Infection Research, Braunschweig, Germany

H. Kusch

Institute for Microbiology and Genetics, University of Göttingen,

Göttingen, Germany 
Table 1 Strains used in this study

\begin{tabular}{lll}
\hline Strain & Genotype/markers & Reference \\
\hline SH1000 & Functional $r s b U^{+}$derivative of 8325-4 & Horsburgh et al. (2001) \\
Newman & High level of clumping factor & Duthie and Lorent (1952) \\
JLA371 & SH1000 hla::lacZ hla $^{+}\left(\right.$Ery $\left.^{\mathrm{R}}\right)$ & Horsburgh et al. (2001) \\
SJF1293 & saeS::Tn551 (SH1000) $\left(\right.$ Ery $\left.^{\mathrm{R}}\right)$ & Needham et al. (2004) \\
SJF1295 & saeR::Tn551 (SH1000) $\left(\right.$ Ery $\left.^{\mathrm{R}}\right)$ & Needham et al. (2004) \\
Reynolds CP5 & Serotype 5 prototype strain $(\mathrm{CP5})$ & Karakawa and Vann (1982) \\
Reynolds $\left(\mathrm{CP}^{-}\right)$ & Capsule-negative mutant of Reynolds (CP5) $\left(\right.$Ery $\left.^{\mathrm{R}}\right)$ & Watts et al. (2005) \\
KC046 & $m r g A:: l a c Z(p A Z 106)\left(\right.$ Ery $\left.^{\mathrm{R}}\right)$ & Cosgrove (unpublished) \\
\hline
\end{tabular}

large reservoir for potential infection (Peacock et al. 2001). As a pathogen, $S$. aureus is highly adaptable, with an alarming spread of antibiotic resistance. This limits the range of effective therapies able to combat this organism. S. aureus is able to cause a wide range of diseases, from minor skin infections to severe systemic disease (such as bacteraemia, septic arthritis and endocarditis). Also, in the hospital environment, $S$. aureus is responsible for many infections associated with surgical wounds and catheters. The ability to inhabit so many niches with such a range of infectious sequelae is due to a large repertoire of virulence determinants.

The human body has many innate defence mechanisms to prevent infection by invading microbes. Physical barriers (human skin and mucosa) prevent pathogens from ingress. The human skin is composed of tightly bound epithelial cells and covered by a highly cross-linked layer of keratin and is therefore normally impenetrable to bacteria (Proksch et al. 2008). Additionally, the skin produces antimicrobial peptides as well as skin fatty acids which are crucial for host defence (Ong et al. 2002; Niyousaba and Ogawa 2005). Several fatty acids have been isolated from human skin, which have strong antimicrobial activity (Miller et al. 1988; Wille and Kydonieus 2003). The antibacterial activity of unsaturated fatty acids has been well known for many years (Kabara et al. 1972; Knapp and Melly 1986; Shin et al. 2007), the most effective antistaphylococcal skin fatty acid being cis-6-hexadecanoic acid (C-6$\mathrm{H}$, sapienic acid, C16:1 $\Delta 6$ ) (Takigawa et al. 2005; Wille and Kydonieus 2003). As well as being antibacterial, C-6-H also has the ability to inhibit virulence determinant production and the induction of antibiotic resistance mechanisms (Clarke et al. 2007; Projan et al. 1994; Schlievert et al. 1992; Takigawa et al. 2005; Kenny et al. 2009). In fact, in murine models of $S$. aureus infection, C-6-H has shown to be an effective treatment. Thus, it is important to understand how C-6-H mediates its effects and the response of $S$. aureus to such assault. A surface protein, IsdA, has been shown to be involved in resistance of $S$. aureus to C-6-H by rendering the cells more hydrophilic (Clarke et al. 2007). Also, wall teichoic acids are required to prevent susceptibility to C-6-H (Kohler et al. 2009).

In order to define bacterial components important in resistance to $\mathrm{C}-6-\mathrm{H}$ and how its effect on virulence determinant expression is mediated, a global study of gene expression and protein profile analysis in response to C-6-H was carried out.

\section{Materials and methods}

\section{Bacterial strains and culture conditions}

Bacterial strains used in this study are listed in Table 1 and were grown in iron-limited tryptic soy broth $\left(\mathrm{TSB}^{-\mathrm{Fe}}\right)$ (Oxoid), Chelex-100 (Sigma Aldrich), with the addition of $20 \mu \mathrm{M}$ 2,2'-dipyridyl (Baldassarri et al. 2001). Antibiotics used were erythromycin $(5 \mu \mathrm{g} / \mathrm{ml})$, lincomycin $(25 \mu \mathrm{g} / \mathrm{ml})$ or tetracycline $(5 \mu \mathrm{g} / \mathrm{ml})$ where appropriate. Cultures were grown at $37{ }^{\circ} \mathrm{C}$ and inoculated with an overnight culture to an optical density at $600 \mathrm{~nm}\left(\mathrm{OD}_{600}\right)$ of 0.05 into $\mathrm{TSB}^{-\mathrm{Fe}}$, followed by incubation with agitation at $37{ }^{\circ} \mathrm{C}$. Bacterial growth was monitored by measuring the $\mathrm{OD}_{600}$.

\section{Bacterial killing assays}

Bacteria were grown to an $\mathrm{OD}_{600}$ of approximately 0.6 in $\mathrm{TSB}^{-\mathrm{Fe}}$. Cells from $10 \mathrm{ml}$ of culture were harvested by centrifugation for $10 \mathrm{~min}$ at $5,000 \times g$ and $4{ }^{\circ} \mathrm{C}$. The cell pellet was washed twice in sterile $\mathrm{dH}_{2} \mathrm{O}$ by resuspension and centrifugation as above. $\mathrm{OD}_{600}$ was measured, and cell suspension was adjusted to $\mathrm{OD}_{600}$ of 1.0. Cells were incubated at $37{ }^{\circ} \mathrm{C}$ with cis-6-hexadecanoic acid (C-6-H; Matreya) and cfu determined at intervals by plating onto $\mathrm{TSB}^{-\mathrm{Fe}}$ agar. For C-6-H pre-exposure experiments, bacteria were grown to an $\mathrm{OD}_{600}$ of $0.5 \mathrm{in} \mathrm{TSB}^{-\mathrm{Fe}}$ and $8 \mu \mathrm{g} / \mathrm{ml}$ C-6-H was added, prior to continued incubation, with shaking, for $2 \mathrm{~h}$ by $37^{\circ} \mathrm{C}$. Cells were then harvested, washed and exposed to $\mathrm{C}-6-\mathrm{H}$ in the killing assay, as above.

Transcriptional analysis

Total RNA was isolated from cultures $\left(\mathrm{OD}_{600}\right.$ of 0.5$)$, prior to, 10 and $60 \mathrm{~min}$ after the addition of $10 \mu \mathrm{g} / \mathrm{ml} \mathrm{C-6-}$ H. "RNAprotect Bacteria Reagent" (QIAGEN, Hilden, 
Table 2 Oligonucleotides used for RT-PCR analysis

\begin{tabular}{|c|c|}
\hline Oligonucleotides & Sequence $\left(5^{\prime}-3^{\prime}\right)$ \\
\hline gyrB_QF & ATCACAGCATTTGGTACAGG \\
\hline gyrB_QR & CGATAGAAGAATGTTAATAACAATGTT \\
\hline ysxC_QF & GCAGTAAAAGAAGAACAATATCC \\
\hline ysxC_QR & GGGTTGCTGTGATGTACG \\
\hline asp23_QF & AAACAACAAGAACAAAATCAAGAG \\
\hline asp23_QR & ACCACCTTCAACAGATACACC \\
\hline hprT_QF & TGTAAGGAATTGGGAGCAC \\
\hline hprT_QR & ACTTCACCAGTTGACTCAG \\
\hline sceD_QF & TCGCATCATCATTAGCAGTAG \\
\hline sceD_QR & GTGATAAGTAAACCCTTCATAGTC \\
\hline saeS_QF & GTATTGGCATTATACCAGAACTAC \\
\hline saeS_QR & GCGAGTTCATTAGCTATATATAAGC \\
\hline saeR_QF & CCAAGGGAACTCGTTTTACG \\
\hline saeR_QR & CATAGGGACTTCGTGACCAT \\
\hline lytS_QF & AAAGTTGAAAGAAGTGCATACTAAAGAAG \\
\hline lytS_QR & TGTACCGACGATAGAACCATG \\
\hline lytR_QF & ATTAGGAGCTAAGATTCAAAAGATG \\
\hline lytR_QR & TTGACTGCTTGTTCAATACG \\
\hline $\operatorname{lrg} \mathrm{A} \_\mathrm{QF}$ & GCATCAAAACCAGCACACTT \\
\hline $\operatorname{lrg} \mathrm{A} \_\mathrm{QR}$ & TGATGCAGGCATAGGAATTG \\
\hline $\operatorname{lrgB} \_\mathrm{QF}$ & TATTTGGTGTGGCCTTCCTC \\
\hline $\operatorname{lrgB} \_\mathrm{QR}$ & AAACAGATTGTTGCCGGTTC \\
\hline PhoP_QF & TCGGGTATTAGGTTTAGAATTAGG \\
\hline PhoP_QR & GGTAATATCATCGTCAATCTCTTC \\
\hline PhoR_QF & AATCCGTCCCATTCAAGAAGTTAC \\
\hline PhoR_QR & AGGCGTCGTGCTAAATCATTG \\
\hline butA_QF & CGTCTGAAGGTATTACTGTGAATG \\
\hline butA_QR & TGAGAAACTCTGCCCAAAGC \\
\hline agrB_QF & TCTGACGGTACTTATGTGAC \\
\hline agrB_QR & CCAGTGCTATTAGTTCCACTG \\
\hline lytM_QF & GCTATACATTCGTAGATGCTCAAG \\
\hline lytM_QR & CTCGCTGTGTAGTCATTGTTATC \\
\hline hla_QF & ATGATAGAGATTCTTGGAACCC \\
\hline hla_QR & AATAACTGTAGCGAAGTCTGG \\
\hline katA_QF & ACGAGATCCTAGAACAAATATGAG \\
\hline katA_QR & GTATGTGTGAGAACCGAACC \\
\hline clfA_QF & AATGATTCAAGTAGCGTTAGTG \\
\hline clfA_QR & TTCGTTGTCGTAGTAGTAGC \\
\hline sarA_QF & GAGTTGTTATCAATGGTCACTTATGC \\
\hline sarA_QR & CAGTTCTTTCATCATGCTCATTACG \\
\hline cidA_QF & СТАСТАCTACAACTAGGAATCATC \\
\hline cidA_QR & TTTAGCGTAATTTCGGAAGC \\
\hline mrgA_QF & AGTACAATCTAACATACCCACAATTTCTTG \\
\hline mrgA_QR & GAGTGCTAATTCAGTTACGACTTTCTTG \\
\hline rsbU_QF & GAAATCGTTAAAGGCTTTGGTTATAG \\
\hline rsbU_QR & GCTCATTGTGCCATCGTTATG \\
\hline spa_QF & GCAAACCATGCAGATGCTAA \\
\hline spa_QR & AACGCTGCACCTAAGGCTAA \\
\hline
\end{tabular}

Germany) was added to $8 \mathrm{ml}$ culture and incubated for $5 \mathrm{~min}$, and cells were harvested by centrifugation $(5,000 \times \mathrm{g}$ for $10 \mathrm{~min}$ at $4{ }^{\circ} \mathrm{C}$ ) and resuspended in $1 \mathrm{ml}$ RLT buffer (Qiagen) including $10 \mu \mathrm{g} / \mathrm{ml} \beta$-mercaptoethanol. Cells were lysed using a Fast Prep shaker (BIO 101 Savant, Haarlem, The Netherlands) for $3 \times 40 \mathrm{~s}$ at a speed of 6.5 units. RNA was isolated using an "RNeasy Mini Kit 250" from QIAGEN. RNA quantity was measured using a NanoDrop 1000 spectrophotometer and the quality checked by analysis with an Agilent 2100 Bioanalyzer (Agilent Technologies, Palo Alto, CA, USA). Reverse transcription and fluorescent labelling reactions were performed using $10 \mu \mathrm{g}$ total RNA, random hexamer primers mix (Invitrogen), SuperScript III ${ }^{\mathrm{TM}}$ Reverse Transcriptase (Invitrogen) and incubation for $1 \mathrm{~h}$ at $50{ }^{\circ} \mathrm{C}$. The cDNA was labelled with Cy3- and Cy5dyed d'CTPs (Amersham) according to the manufacturer's instructions (Scienion, Berlin, Germany).

RNA obtained from three independent biological experiments was utilised, and a dye switch experiment was performed to minimise errors based on the differential dye bleaching or incorporation absorption of $\mathrm{Cy} 3$ and $\mathrm{Cy} 5$ during the RT reaction. The microarray hybridization and washing of the slides were carried out as recommended by the manufacturer (Scienion, Berlin). Microarray hybridization was at $49{ }^{\circ} \mathrm{C}$ for $48 \mathrm{~h}$. The microarrays (Scienion) contained the full genome of $S$. aureus N315. Each slide contained PCR products of 2,334 genes in duplicate copies of each open reading frame (ORF) and multiple controls. Slides were scanned using a Genepix 4000B laser scanner (Axon Instruments Inc., Union City, CA, USA), and the individual signal intensity was analysed using Acuity 4.0 software, according to the manufacture's instructions. Briefly, data were normalised to the mean ratio of means of all features, and all experiments were normalised to each other. Standard deviations and mean values of gene expression ratios based on the two spot replicates on each microarray and three different hybridisation experiments were calculated. Significant changes in gene expression were identified by a mean ratio $<0.5$ or $>2.0$ and a $p$ value $<0.05$.

Real-time polymerase chain reaction (RT-qPCR)

RNA was isolated as described for the transcriptional analysis. Two microgram of RNA was reverse-transcribed to cDNA as above. Master mixes were prepared according to the manufacturer's instructions, using oligonucleotides specific for target genes listed in Table 2. SYBR Green (SensiMixPlus SYBR, Quantace, London, UK) was used as a fluorescent nucleic acid dye. RT-qPCR was performed in a Mx3000P Real-Time PCR System (Stratagene), and the following temperature profile was used for amplification. The initial denaturation was at $95{ }^{\circ} \mathrm{C}$ for $10 \mathrm{~min}$, and 
templates were amplified by 40 cycles at $95^{\circ} \mathrm{C}$ for $30 \mathrm{~s}$ and $54{ }^{\circ} \mathrm{C}$ for $1 \mathrm{~min}$. A final step, $1 \mathrm{~min}$ at $95{ }^{\circ} \mathrm{C}, 30 \mathrm{~s}$ at $54{ }^{\circ} \mathrm{C}$ and $30 \mathrm{~s} 95{ }^{\circ} \mathrm{C}$ was used. A dissociation curve was generated to ensure amplification of a single product and absence of primer dimmers (Nolan et al. 2006). Three reference genes ( $g y r B$, yneR and $y s x C$ ) were used which showed no significant change in expression on microarrays at all times and under all conditions. For calculation of the relative levels of gene expression, only gyrB was used as the endogenous reference gene.

\section{Preparation of protein extracts}

For the preparation of extracellular protein extracts, cytoplasmic protein extracts, ionically bound proteins and membrane proteins, bacteria were grown in $\mathrm{TSB}^{-\mathrm{Fe}}\left(\begin{array}{ll}1 & 1\end{array}\right)$ to exponential phase $\left(\mathrm{OD}_{600}\right.$ of 1.0$)$ and stationary phase (16 h).

Cells were harvested by centrifugation $(9,000 \times g$ for $10 \mathrm{~min}$ ), and extracellular proteins from the supernatant were precipitated using $100 \% \mathrm{w} / \mathrm{v}$ fresh TCA $(10 \% \mathrm{w} / \mathrm{v}$ final volume) and incubated on ice for $30 \mathrm{~min}$. Proteins were harvested by centrifugation $(9,000 \times g$ for $5 \mathrm{~min})$, and the pellet was washed 5 times with $100 \% \mathrm{v} / \mathrm{v}$ acetone and air-dried for $1.5 \mathrm{~h}$. The precipitated proteins were then washed twice with $100 \% \mathrm{v} / \mathrm{v}$ ethanol, once with $70 \% \mathrm{v} / \mathrm{v}$ ethanol and finally with $100 \% \mathrm{v} / \mathrm{v}$ ethanol, prior to air-drying the pellet overnight at room temperature (RT). Proteins were dissolved in urea solution ( $8 \mathrm{M}$ urea, $2 \mathrm{M}$ thiourea), with incubation at RT for $30 \mathrm{~min}$. In order to remove insoluble proteins, the suspension was centrifuged for $5 \mathrm{~min}$ at $20,000 \times g$. The protein concentration was determined for each sample and adjusted to $200 \mu \mathrm{g}$ protein.

For the isolation of the cytoplasmic proteins, harvested cells were broken by FastPrep as above and the suspension then centrifuged at $20,000 \times g$ for $10 \mathrm{~min}$ at $4{ }^{\circ} \mathrm{C}$. The ensuing supernatant was centrifuged at $150,000 \times g$ for $2 \mathrm{~h}$ at $4{ }^{\circ} \mathrm{C}$, using an ultracentrifuge (Optima ${ }^{\mathrm{TM}} \mathrm{LE}-80 \mathrm{~K}$, Beckman, USA). The supernatant was then centrifuged as above, and the cytoplasmic proteins were then precipitated using $10 \% \mathrm{w} / \mathrm{v}$ TCA and prepared as described above (for supernatant proteins).

\section{Analytical and preparative 2D-PAGE}

Two-dimensional polyacrylamide gel electrophoresis (2D-PAGE) was performed by using the immobilized $\mathrm{pH}$ gradient (IPG) technique as described previously (Bernhardt et al. 1999). First, protein samples were separated on linear IPG strips (ImmobilineTM DryStrips, GE Healthcare, Little Chalfont, UK). For extracellular and ionically bound protein samples, strips in the $\mathrm{pH}$ range 3-10 were used, and for cytoplasmic protein samples, the $\mathrm{pH}$ range
4-7 was used. 2D gels were loaded with $200 \mu \mathrm{g}$ protein extract, and the resulting gels were fixed with $50 \% \mathrm{v} / \mathrm{v}$ ethanol and $3 \% \mathrm{v} / \mathrm{v}$ acetic acid, for $30 \mathrm{~min}$. Afterwards, 2D gels were stained with SYPRO ${ }^{\circledR}$-Ruby and fixed with $10 \%$ $\mathrm{v} / \mathrm{v}$ methanol and $7 \% \mathrm{v} / \mathrm{v}$ acetic acid. The stained gels were finally scanned using a Typhoon 9400 Variable Mode Imager (Amersham Biosciences, Freiburg, Germany). For protein identification by matrix-assisted laser desorption ionisation-time-of-flight mass spectrometry (MALDI-TOFMS), SYPRO stained protein spots were cut from gels using a spot cutter (Proteome Work ${ }^{\mathrm{TM}}$ ) with a picker head of $2 \mathrm{~mm}$ and transferred into 96-well microtiter plates. The proteins were digested with trypsin, and subsequent spotting of peptide solutions onto MALDI targets was performed automatically by using an Ettan Spot Handling Workstation (GE Healthcare, Little Chalfont, UK) using a standard protocol as previously described (Eymann et al. 2004). Actual analyses of spotted peptide solutions were performed as previously described (Wolf et al. 2008).

\section{Results and discussion}

\section{Induced resistance of S. aureus to C-6-H}

To determine whether $S$. aureus responds to $\mathrm{C}-6-\mathrm{H}$, the effect of preincubation with a sub-MIC level of the fatty acid on resistance was determined. Firstly, to confirm the bactericidal effect of C-6-H, SH1000 was grown in TSB ${ }^{-}$ $\mathrm{Fe}$ to early exponential phase and challenged with 10 or $20 \mu \mathrm{g} / \mathrm{ml} \mathrm{C}-6-\mathrm{H}$ over $2 \mathrm{~h}$. We observed a rapid decrease in survival rate. At $t=40 \mathrm{~min}$, cells treated with $10 \mu \mathrm{g} / \mathrm{ml}$ showed only $1.3 \%$ survival and cells treated with $20 \mu \mathrm{g} / \mathrm{ml}$ C-6-H showed a survival rate of $1 \%$ (Fig. 1). The untreated control showed over $55 \%$ survival after 120 min. Conversely, those cells previously exposed to subgrowth inhibitory level of C-6-H were much more resistant than naïve cells. After 1 h, $99 \%$ of naïve cells were dead compared with only $12 \%$ of those pretreated (Fig. 2). This indicates that $S$. aureus responds to $\mathrm{C}-6-\mathrm{H}$ treatment by the induction of a resistance mechanism. In order to find out the level of C-6-H-induced resistance, additional assays were performed. C-6-H pretreated cells were incubated with 30 , 40, 50 and $60 \mu \mathrm{g} / \mathrm{ml} \mathrm{C-6-H}$ in the killing assay (Fig. 3). Pretreated cells showed resistance up to $50 \mu \mathrm{g} / \mathrm{ml} \mathrm{C}-6-\mathrm{H}$ challenge. Challenge with $50 \mu \mathrm{g} / \mathrm{ml} \mathrm{C}-6-\mathrm{H}$ killed over $99.9 \%$ of naïve cells after 60 min of incubation, whereas pretreated cells were $80 \%$ killed after this time. However, once $60 \mu \mathrm{g} / \mathrm{ml} \mathrm{C}-6-\mathrm{H}$ was used the induced resistance threshold was reached. There is no difference in sensitivity to $\mathrm{C}-6-\mathrm{H}$ between the preincubated and non-preincubated cells (Fig. 3). Thus, a resistance mechanism is induced in response to C-6-H. S. aureus is an extremely adaptable 


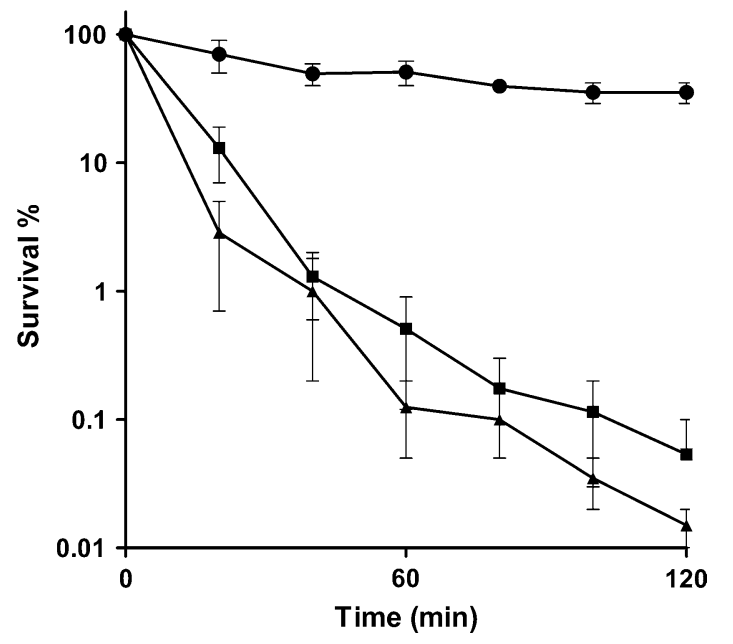

Fig. 1 Bactericidal effect of C-6-H on strain SH1000 wt. SH1000 was grown in $\mathrm{TSB}^{-\mathrm{Fe}}$ until $\mathrm{OD}_{600} 0.5-0.6$. Cells were harvested, washed with $\mathrm{dH}_{2} \mathrm{O}$ and challenged with 0 (filled circle), 10 (filled square) or 20 (filled triangle) $\mu \mathrm{g} / \mathrm{ml} \mathrm{C-6-H}$ over $2 \mathrm{~h}$. Samples were taken, and cfu was determined over time. Samples were plated in triplicate, and each experiment was repeated twice. Error bars indicate the standard error of the mean

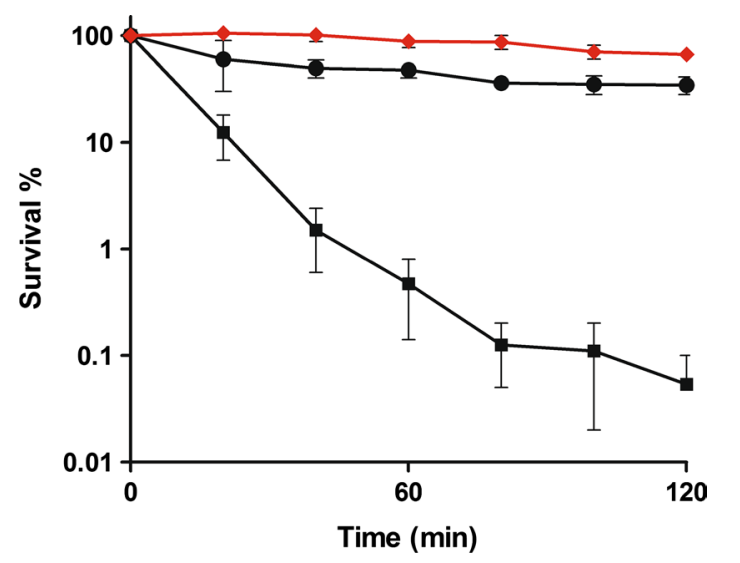

Fig. 2 Induced C-6-H resistance of $\mathrm{SH} 1000$ by pre-incubation with a sub-MIC of C-6-H. SH1000 was grown in $\mathrm{TSB}^{-\mathrm{Fe}}$ with or without $10 \mu \mathrm{g} / \mathrm{ml} \mathrm{C}-6-\mathrm{H}$ until $\mathrm{OD}_{600}$ 0.5-0.6. Cells were harvested, washed with $\mathrm{dH}_{2} \mathrm{O}$ and challenged with 0 (filled circle), 10 (filled square) or 10 with preincubation (filled diamond) $\mu \mathrm{g} / \mathrm{ml} \mathrm{C}-6-\mathrm{H}$ over $2 \mathrm{~h}$. Samples were taken, and cfu was determined over time. Samples were plated in triplicate, and each experiment was repeated twice. Error bars indicate the standard error of the mean

organism able to respond to environmental assault. Chan and Foster (1998) reported an increase in resistance to acid stress ( $\mathrm{pH} 2$ ), when the cells were pre-exposed to nonlethal $\mathrm{pH} 4$. How cells become more resistant to $\mathrm{C}-6-\mathrm{H}$ is unknown, but no alteration in solvent partitioning by the cells was seen (data not shown). Cells grown in iron-limited conditions (as here) express $i s d A$, which renders them hydrophilic (Clarke et al. 2007). IsdA is a major surface

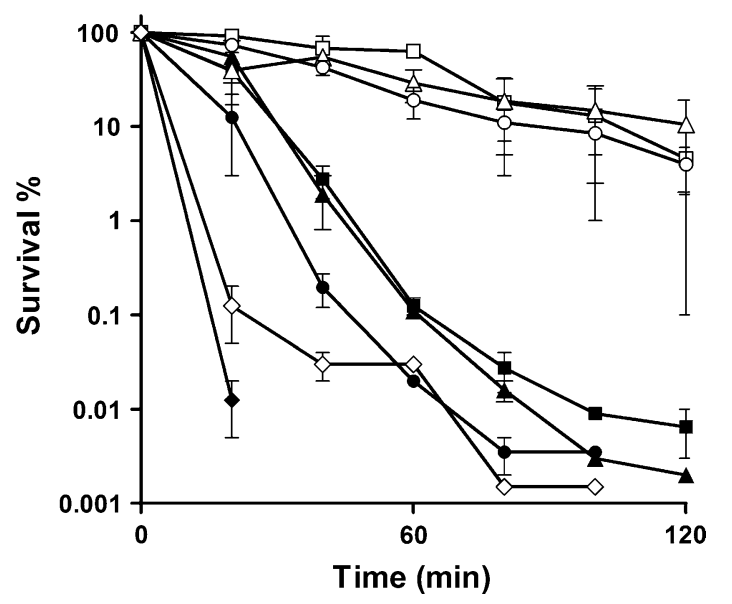

Fig. 3 Bactericidal effect of C-6-H on cells preincubated with a subMIC concentration. SH1000 was grown in $\mathrm{TSB}^{-\mathrm{Fe}}$ with (open sym-

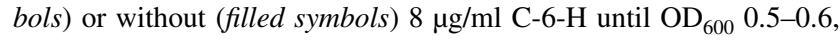
as described in chapter 2. Cells were harvested, washed with $\mathrm{dH}_{2} \mathrm{O}$ and challenged with 30 (open square, filled square), 40 (open triangle, filled triangle), 50 (open circle, filled circle) or 60 (open diamond, filled diamond) $\mu \mathrm{g} / \mathrm{ml} \mathrm{C-6-H.} \mathrm{Samples} \mathrm{were} \mathrm{taken,} \mathrm{and} \mathrm{cfu} \mathrm{was}$ determined over time. Samples were plated in triplicate, and each experiment was repeated twice. Error bars indicate the standard error of the mean

protein and has multiple roles as an adhesin, as a resistance determinant against human innate defences (including C-6$\mathrm{H}$ ), and is required for $S$. aureus survival on human skin (Clarke et al. 2004, 2007; Clarke and Foster 2008; Clarke 2010).

Effect of C-6-H on global gene transcription

In order to determine mechanisms involved in response to $\mathrm{C}-6-\mathrm{H}$, including induction of resistance and inhibition of virulence determinant production, transcriptional profiling was carried out. The expression patterns from exponential phase culture of $S$. aureus SH1000 with and without $10 \mu \mathrm{g} / \mathrm{ml} \mathrm{C}-6-\mathrm{H}$ were compared. Under these conditions, C-6-H has no significant effect on growth rate or yield. Culture samples for analysis were taken $10 \mathrm{~min}$ and $60 \mathrm{~min}$ after C-6-H addition. After 10-min incubation with C-6-H, 290 genes were decreased and 293 genes were increased in expression level (Table S1). Besides many genes of unknown function and those encoding hypothetical proteins, there were also many genes whose expression was altered by C-6-H which encode ABC transporters, bacterial secretion systems, cell wall metabolism components, DNA replication and repair pathways as well as central metabolic and pathogenicity determinants. After 60-min incubation with C-6-H, 57 genes were reduced and 92 genes were increased in expression level compared with the untreated control (Table S1). These include genes encoding proteins involved 
in $\mathrm{ABC}$ transporter systems, metabolism of coenzymes and prosthetic groups, amino acid synthesis, stress response and many genes involved in virulence of $S$. aureus.

\section{Effects of C-6-H on purine and pyrimidine biosynthesis}

The greatest decrease in expression after 10-min C-6-H incubation was shown by genes encoding proteins involved in purine and pyrimidine biosynthesis (Table S1). In particular, pyrR, pyrP, pyrB, pyrC, pyrAA, pyrAB, pyrF and pyrE of the de novo pyrimidine metabolism were significantly down-regulated (spot vol. ratio $0.09 \pm 0.04$ ) in the presence of C-6-H compared with the control. This whole operon is regulated by $p y r R$ and strongly depends on the presence of pyrimidine nucleotides (Turner et al. 1994; Paulus et al. 1982). Synthesis of pyrimidine is crucial for the cells to divide and therefore cell survival (Turnbough and Switzer 2008). The regulator $p y r R$ showed a decrease in expression (spot vol. ratio of $0.06)$ in the presence of $\mathrm{C}-6-\mathrm{H}$ (10-min incubation). Interestingly, after 60-min incubation with C-6-H, the operon pyrR$E$ (SA1041-SA1048) was highly increased in expression (Table S1). The regulator pyrR is increased in expression (spot vol. ratio 19.6), and genes $p y r P, p y r B, p y r C$ and $p y r A B$ were even more (spot vol. ratio $25 \pm 5$ ) up-regulated in expression, suggesting that the rapid response $(10 \mathrm{~min})$ of $S$. aureus to C-6-H may alter the intracellular pyrimidine pool, thus requiring increased expression of the genes after the initial adaptation period. Interestingly, the response to C-6-H may be specific as Kenny et al. (2009) reported no effect of linoleic or oleic acid on expression of genes involved in pyrimidine biosynthesis. How C-6-H and other fatty acids effect bacteria and differential responses alludes to fatty acid-specific mechanisms.

Genes that are involved in purine metabolism such as xprT (xanthine phosphoribosyltransferase), guaA (GMP synthase), guaB (inositol-monophosphate dehydrogenase) and relA(rsh) (GTP pyrophosphokinase) also showed a strong decrease in expression in the presence of C-6- $\mathrm{H}$ after 10-min incubation (spot vol. ratio $0.3 \pm 0.2$ ) (Table $\mathrm{S} 1)$. After 60-min C-6-H incubation, the expression of $x p r T$, guaA, guaB but not relA was still decreased. Interestingly, RelA as well as enzymes of the purine biosynthetic pathway has been described to be involved in resistance to lysostaphin (Gründling et al. 2006). Further, RelA (Rsh) may be important in the response to C-6-H as it effects the expression of a number of genes, including cap (via CodY) (Geiger et al. 2010; Pohl et al. 2009; Srivatsan and Wang 2008; Wolz et al. 2010).

\section{Effects of C-6-H on cellular transport systems}

The microarray data demonstrated that many genes encoding for $\mathrm{ABC}$ transporters were effected in expression in the presence of C-6-H. Two genes, cbiO (Cobalt import ATP-binding protein Cibo1) and cibO2 (Cobalt import ATP-binding protein $\mathrm{CibO} 2$ ), which are part of the cobalt transporter, are decreased in expression. After 10-min incubation with $\mathrm{C}-6-\mathrm{H}$, microarray data showed a spot vol. ratio of 0.42 and 0.49. Cobalt is an essential cofactor for several enzymes and other components such as vitamin B12 and must be imported into the cell (Kobayashi and Shimizu 1999). Surprisingly, other genes involved in cobalt transport such as $c b i Q$ (transmembrane component) and cbiN (small membrane-bound component) were not affected in expression by C-6-H. After 60-min incubation with C-6-H, the $c b i O$ genes showed no change in expression compared with the control (Table S1).

The expression of three genes, potA, potB and potC, from the potABCD operon were down-regulated after 10-min C-6-H incubation with a spot vol. ratio of $0.28 \pm 0.05$. After $60-$ min incubation with $\mathrm{C}-6-\mathrm{H}$, the expression of genes from the potABCD operon showed no change compared with the control. The operon encodes an $\mathrm{ABC}$ transporter that transports polyamines such as putrescine and spermidine across the membrane. Polyamines play an important role in cell proliferation and differentiation, as shown in E. coli (Kashiwagi et al. 1993).

Interestingly, the genes encoding for a putative monovalent cation $/ \mathrm{H}^{+}$antiporter were increased in expression in the presence of C-6-H (spot vol. ratio of $2.1 \pm 0.1$ ). SA0578 (putative antiporter subunit A), SA0579 (putative antiporter subunit B), SA0580 (putative antiporter subunit C), SA0581 (putative antiporter subunit D), SA0583 (putative antiporter subunit E) and SA0584 (putative antiporter subunit F) may be part of a $\mathrm{Na}^{+} / \mathrm{H}^{+}$antiporter which is involved in resistance to high concentrations of $\mathrm{K}^{+}, \mathrm{Li}^{+}$ and $\mathrm{Na}^{+}$ions. Antiporters play an important role in circulating $\mathrm{Na}^{+}$and $\mathrm{H}^{+}$across the cytoplasmic membrane (Padan and Schuldiner 1994) and are also important for the internal $\mathrm{pH}$ maintenance. Recently, we reported the bactericidal mechanisms of $\mathrm{C}-6-\mathrm{H}$ at different concentrations (Cartron et al. 2014). C-6-H has multiple effects on the cell membrane including loss of the ability to maintain intracellular $\mathrm{pH}$.

Compared with the genes that were affected after 10-min incubation, a completely different set was affected (positively as well as negatively) in expression after incubation with C-6-H for $60 \mathrm{~min}$. The array data revealed that the genes sirA, proP, fhuA, glpF and SA2339 were increased in expression by C-6-H incubation. Interestingly, the gene SA2339 is highly up-regulated (spot vol. ratio over 11) in expression in the presence of C-6-H. SA2339 is, according to the database (NCBI), a hypothetical protein which shows similarities to an antibiotic transport-associated protein. The sirA gene (staphylococcal iron regulator) encodes for a lipoprotein, and the microarray data revealed a spot vol. 
ratio of 2.9, only after 60-min C-6-H incubation. The sirA gene is part of the operon $\operatorname{sir} A B C$. Heinrichs et al. (1999) reported that SirA acts as a membrane-associated siderophore-binding protein. The operon is iron regulated, and transcription is controlled by the Fur protein (Heinrichs et al. 1999). Interestingly, the regulatory gene fur showed a down-regulation (spot vol. ratio 0.48) after 10-min incubation with C-6-H. The fur gene encodes for the ferric uptake regulator which controls cellular iron homoeostasis (Horsburgh et al. 2001).

Furthermore, the gene fhuA (ferrichrome transport ATPbinding protein) was increased in expression after 60-min C-6-H incubation (spot vol. ratio 2.4). The fhuA gene is part of the fhu system which encodes for a ferric hydroxamate uptake system and therefore involved in iron acquisition from hydroxamate siderophore (Sebulsky et al. 2000). Interestingly, none of the other genes that belong to the fhu system were affected in expression by C-6-H. The fhuD 2 gene (spot vol. ratio 3.9) showed an increase in expression after 60-min C-6-H treatment. Sebulsky et al. (2003) reported that fhuD2 encodes an iron (III)-siderophorebinding protein. After binding a siderophore, the FhuD2siderophore complex will be recognised by the Fhu system. Iron is one of the most important nutrients for $S$. aureus and is required for various key metabolic processes. Its acquisition is vital for survival. The $\operatorname{sir} A B C$ operon as well as the $f h u$ genes is crucial components in the iron acquisition process.

The gene proP, which encodes for a proline/betaine transporter homologue (MacMillan et al. 1999), was increased (spot vol. ratio 2.4) in expression in the presence of C-6-H at 60 min only (Table S1). This transporter is important in balancing osmotic differences between $S$. aureus and its environment. The proP gene is part of the VraSR regulon, which includes 13 genes in total and is involved in regulation of the cell wall biosynthesis pathway (Kuroda et al. 2003).

Effects of C-6-H on the cell envelope and cell wall synthesis

The expression of many genes involved in cell envelope biogenesis, including lytM, dltABD, cidA, pbp2 and $p b p 4$, was altered in response to $\mathrm{C}-6-\mathrm{H}$ treatment. The peptidoglycan hydrolase LytM (autolysin) plays a role in cell wall turnover as well as cell division (Ramadurai et al. 1999). After 10-min incubation with C-6-H, the expression of lyt $M$ was decreased (spot vol. ratio 0.48 ) in expression, whereas after 60-min incubation no change in expression was observed. LytM hydrolyses peptidoglycan, and it has been proposed that it might play a role in the lysis of cells initiated by cell wall-acting antibiotics (Kusser and Ishiguro 1988), suggesting that C-6-H may induce lysis.
Genes of the $\operatorname{dlt} A B C D$ operon, which is important for D-alanylation of wall teichoic acids (WTA) as well as lipoteichoic acids (LTA), showed a strong decrease in expression in the presence of C-6-H after 10-min treatment. After 60-min C-6-H incubation, no change in expression of the dltABCD was observed. The dltA gene (spot vol. ratio 0.15 ) encodes a D-Alanyl carrier protein ligase and activates D-alanine using ATP. Also, $d l t B$, a predicted transmembrane protein, and $d l t D$, a membrane protein (Neuhaus and Baddiley 2003), showed a spot vol. ratio of $0.25 \pm 0.02$. Surprisingly, $d l t C$ expression showed no effect of C-6-H in the microarray data. Koprivnjak et al. (2006) reported that the dltABCD operon is highly repressed by a rising concentration of monovalent and divalent $\left(\mathrm{Mg}^{2+}\right)$ cations. This group also mentioned that the transcriptional regulation may be partly due to the ArlSR two-component system. (Koprivnjak et al. 2006)

Weidenmaier et al. (2005) reported the role of the dltABCD operon in mediating resistance to cationic antimicrobial peptides (CAMP). DltABCD is able to modify negatively charged cell envelope components with positively charged amino acids, to enhance the net positive surface charge of $S$. aureus leading to CAMP resistance (Peschel 2002). The down-regulation (due to $\mathrm{C}-6-\mathrm{H})$ of $\operatorname{dlt} A B D$ expression may affect surface charge. Kohler et al. (2009) showed that wall teichoic acids, which play an important role in $S$. aureus surface charge, are crucial for protection of $S$. aureus against human skin fatty acids such as C-6-H. However, the treatment with $\mathrm{C}-6-\mathrm{H}$ showed a strong decrease in expression of the dltABCD operon within the first few minutes but then recovers.

Penicillin-binding proteins 2 and 4 had altered expression (spot vol. ratios of 2.04 and 0.46 , respectively) after 10-min incubation with C-6-H. PBP2 is involved in cell wall metabolism and methicillin resistance (Giesbrecht et al. 1998), and PBP4 is mainly involved in secondary crosslinking of the peptidoglycan layer (Henze and BergerBachi 1996), further suggesting that the cell wall of $S$. aureus is involved in protection against fatty acids.

The regulator lytSR, which encodes for a sensor histidine kinase (LytS) and a response regulator (LytR), was reduced (spot vol. ratio $0.38 \pm 0.04$ ) after 10-min C-6-H incubation (Table S1). LytSR is a sensor-regulator system with both positive and negative regulatory effects on murein hydrolase activity and autolysis (Brunskill and Bayles 1996). It is proposed that LytSR is able to sense a decrease in membrane potential and initiates the transcription of $\operatorname{lrg} A B$ (Patton et al. 2006; Bayles 2007). The $\operatorname{lrg} A B$ genes are involved in the regulation of murein hydrolase activity and may play a role in autolysin regulation (Groicher et al. 2000; Bayles 2003). Further studies reported that the cidA gene encodes for a holing-like membrane protein that is an effector of 
murein hydrolase activity and cell lysis, whereas $\operatorname{lrg} A$ encodes an antiholin that is an inhibitor of CidA (Groicher et al. 2000; Rice et al. 2003). Interestingly, the array data showed that the expression of $\operatorname{lrg} A B$ is highly increased after 10-min incubation with C-6-H (spot vol. ratios of 89 and 20, for $\operatorname{lrg} A$ and $\operatorname{lrg} B$, respectively) (Table S1) even if its regulatory activator (lytSR) is inhibited in expression by C-6-H. $\operatorname{Lrg} \mathrm{A}$ and $\mathrm{LrgB}$ are involved in regulation of peptidoglycan hydrolase activity by reducing extracellular activity (Groicher et al. 2000; Bayles 2003). Bayles (2007) suggested that $\operatorname{Lrg} \mathrm{AB}$ together with their antagonist proteins CidAB was involved in the control of bacterial death and lysis during biofilm formation. Interestingly, the expression of $c i d A$ was decreased after 10-min C-6-H incubation (spot vol. ratio over 4). The $c i d A$ gene is in an operon with $c i d B$. The $c i d B$ gene showed no change in expression levels in the presence of $\mathrm{C}-6-\mathrm{H}$, but $c i d A$ was decreased in expression and cidC was increased in its expression, respectively.

Further, Rice et al. (2003) showed that a lytSR mutation leads to an increase in autolysis rate and a decrease in $\operatorname{lrg} A B$ expression. These data were confirmed when Sharma-Kuinkel et al. (2009) reported that a mutation in the lyt $S$ gene showed a drastic decrease in the expression of $\operatorname{lrg} A B$ operon. Interestingly, in this study, the expression of lytSR showed a decrease in its transcription in the presence of $\mathrm{C}-6-\mathrm{H}$ and the expression of the $\operatorname{lrg} A B$ operon was highly increased in its expression, suggesting that there might be an additional so far unknown regulatory system involved in $\operatorname{lrg} A B$ control.

We have observed that the bactericidal activity of C-6-H occurs via a variety of mechanisms, including loss of proton motive force (PMF) (Cartron et al. 2014), which may lead to an increase in lytSR expression.

The biological role of the $\operatorname{lrg}$ and $c i d$ operons has been suggested to be in the control of cell death and lysis during biofilm formation, as well as release of genomic DNA to promote intracellular adhesion in biofilm stability (Bayles 2007). The increased $\operatorname{lrg} A B$ expression and decreased expression of cidA may be due to cell wall stress and is a response that may prevent cell death due to metabolic perturbation. In a separate study, Kenny et al. (2009) observed a decrease of $\operatorname{lrg} A$ expression in response to linoleic acid, which demonstrates distinct responses to specific unsaturated long-chain fatty acids by $S$. aureus.

Capsule biosynthesis genes (cap) showed a significant increase in expression (spot vol. ratio of 2.4-7) (Table $\mathrm{S} 1)$. The capsule is involved in the pathogenicity of $S$. aureus by preventing phagocytosis and killing by macrophages (O'Riordan and Lee 2004). Thus, it was possible that the capsule may represent a C-6-H resistance mechanism. Strain SH1000 is not highly encapsulated, and so the role of capsule was determined using strain Reynolds. Killing assays using strain Reynolds and corresponding cap strains did not show any significant differences in C-6-H susceptibility (data not shown). Kenny et al. (2009) also observed an increase in cap gene expression in response to linoleic acid by strain MRSA252. As the capsule has an antiphagocytic effect, it may be that hostassociated stresses (such as C-6-H) lead to its induction as a general response.

Effects of C-6-H on the expression of virulence determinants

Clarke et al. (2007) have previously reported a decrease in toxin production in response to C-6-H. The microarray data revealed altered expression of many genes involved in pathogenicity. After incubation with $\mathrm{C}-6-\mathrm{H}$, virulenceassociated genes such as nuc, hla, hlb, rsbU, sarZ, sarA, clfA and two-component regulator saeRS were effected in expression (Table S1).

The thermonuclease $(n u c)$ is an extracellular protein that degrades double- and single-stranded DNA and RNA. After 10-min incubation with $\mathrm{C}-6-\mathrm{H}$, the expression of nuc was decreased (spot vol. ratio 0.3), but after 60-min treatment with C-6-H the expression of $n u c$ was increased (spot vol. ratio 2.4). The degradation of extracellular DNA plays an important role in host immune evasion to escape from neutrophils extracellular traps (NETs) (Berends et al. 2010).

Besides, the two-component regulator saeRS that encodes for a histidine kinase and a response regulator was affected by -6-H (Giraudo et al. 1999). After 10-min incubation with C-6-H, the expression of saeRS genes was decreased (spot vol. ratio 0.4). Novick and Jiang (2003) reported two additional ORFs in the SaeRS system, saeP and $s a e Q$, which are likely to be important for the function of the operon (Adhikari and Novick 2008; Geiger et al. 2008). The saeP gene, but not saeQ, was decreased in expression (spot vol. ratio 0.28) after incubation with C-6-H for $10 \mathrm{~min}$.

Previous reports have shown that SaeRS activates the expression of $\alpha$-haemolysin (hla), $\beta$-haemolysin (hlb), fibronectin-binding protein $(f n b A$ and $f n b B)$, protein A (spa), coagulase (coa), thermonuclease (nuc), extracellular adherence protein Eap, IgG-binding protein $(s b i)$ and extracellular matrix-binding protein Emp (Giraudo et al. 1994, 1997; Goerke et al. 2001, 2005; Harraghy et al. 2005). Furthermore, it represses the expression of V8 serine protease ( $s p A)$ and capsular polysaccharide (type 5) (cap5). As many of those virulence determinants (e.g. hla, hlb, fnbA, nuc) were decreased in expression due to $\mathrm{C}-6-\mathrm{H}$, this may be due to the activity of SaeRS (Table S1).

There was differential expression of surface proteins in response to C-6-H. Clumping factor A (clfA), a fibrinogenbinding protein, showed a high increase in expression after 
Table 3 Effect of C-6-H on expression of genes determined by qRT-PCR

\begin{tabular}{|c|c|c|c|c|c|c|}
\hline \multirow[t]{2}{*}{ ORF N315 } & \multirow[t]{2}{*}{ Gene } & \multirow[t]{2}{*}{ Gene product } & \multicolumn{2}{|c|}{ Fold change RT-PCR } & \multicolumn{2}{|c|}{$\begin{array}{l}\text { Spot vol ratio } \\
\text { (microarray) }\end{array}$} \\
\hline & & & $10 \mathrm{~min}$ & $60 \mathrm{~min}$ & $10 \mathrm{~min}$ & $60 \mathrm{~min}$ \\
\hline \multicolumn{7}{|c|}{ Cell envelope and cell wall } \\
\hline SA0252 & $\operatorname{Irg} A$ & Holin-like protein $\mathrm{LrgA}$ & 5.00 & 0.27 & 89.97 & 1.00 \\
\hline SA0253 & $\operatorname{Irg} B$ & Holin-like protein LrgB & 4.00 & 0.43 & 20.73 & 1.00 \\
\hline SA0265 & IytM & Peptidoglvcan hydrolase & 1.00 & 3.00 & 0.49 & 1.00 \\
\hline SA2329 & $\operatorname{cidA}$ & Holin-like protein CidA & 0.23 & 1.00 & 0.22 & 1.00 \\
\hline \multicolumn{7}{|c|}{ Virulence factors and regulators } \\
\hline SA0250 & lyt $S$ & Two-component sensor histidine kinase & 0.44 & 1.00 & 0.43 & 1.00 \\
\hline SA0251 & lytR & Two-component response regulator & 1.00 & 1.00 & 0.35 & 1.00 \\
\hline SA0573 & $\operatorname{sar} A$ & Staphylococcal accessory regulator A & 2.00 & 1.00 & 2.37 & 1.00 \\
\hline SA0660 & saes & Histidine protein kinase & 1.00 & 1.00 & 0.44 & 1.00 \\
\hline SA0661 & saeR & Response regulator & 1.00 & 1.00 & 0.41 & 1.00 \\
\hline SA0742 & clfA & Fibrinogen-binding protein A, clumping factor & 1.00 & 1.00 & 6.54 & 1.00 \\
\hline SA1007 & hla & Alpha-haemolysin & 0.41 & 0.07 & 1.00 & 0.13 \\
\hline SA1842 & $\operatorname{agr} B$ & Accessory gene regulator B & 3.00 & 1.00 & 1.00 & 1.00 \\
\hline SA1872 & $r s b U$ & SigmaB regulation protein $\mathrm{RsbU}$ & 1.00 & 1.00 & 0.49 & 1.00 \\
\hline \multicolumn{7}{|c|}{ Stress response } \\
\hline SA1170 & katA & Catalase & 3.00 & 1.00 & 5.06 & 1.00 \\
\hline SA1984 & asp23 & Alkaline shock protein 23, ASP23 & 1.00 & 1.00 & 7.52 & 1.00 \\
\hline \multicolumn{7}{|c|}{ Butanoate metabolism } \\
\hline SAO122 & butA & Acetoin reductase & 5.00 & 1.00 & 16.89 & 2.72 \\
\hline \multicolumn{7}{|c|}{ Transcriptional regulator } \\
\hline SA0641 & $m r z A$ & HTH-type transcriptional regulator MgrA (NorA) & 1.00 & 1.00 & 0.50 & 1.00 \\
\hline SA1515 & phoR & Alkaline phosphatase synthesis sensor protein & 1.00 & 1.00 & 1.00 & 1.00 \\
\hline SA1516 & phoP & Alkaline phosphatase synthesis transcriptional regulation & 1.00 & 1.00 & 3.31 & 1.00 \\
\hline \multicolumn{7}{|c|}{ Purine and/ or pyrimidine metabolism } \\
\hline SA0468 & hprT & Hypoxanthine-guanine phosphoribosyltransferase homologue & 1.00 & 1.00 & 0.29 & 1.00 \\
\hline \multicolumn{7}{|c|}{ Unknown functions and hypothetical proteins } \\
\hline SA1898 & $s c e D$ & Hypothetical protein, similar to SceD precursor & 1.00 & 3.00 & 1.00 & 3.18 \\
\hline \multicolumn{7}{|c|}{ Housekeeping genes } \\
\hline SA0005 & gyrB & DNA gyrase subunit B & 1.00 & 1.00 & 1.00 & 1.00 \\
\hline SA1186 & & Hypothetical protein, homologue toyneS from B. subtilis & 1.00 & 1.00 & 1.00 & 1.00 \\
\hline SA1497 & $y s x C$ & Ribosome biogenesis GTP-binding protein YsxC & 1.00 & 1.00 & 1.00 & 1.00 \\
\hline
\end{tabular}

10-min C-6-H incubation (spot vol. ratio 6.5). The ClfA protein plays an important role in the adhesion to host cells (McDevitt et al. 1994) and is responsible for clumping in host blood plasma (McDevitt et al. 1997). Kenny et al. (2009) reported a similar observation, where clfA expression is up-regulated. Interestingly, the surface proteinencoding genes $f n b A$ and $f n b B$ were decreased in expression by C-6-H. FnbA and B are cell surface-associated proteins which mediate the attachment to host cells (e.g. endothelial cells) and can also act during invasion (Peacock et al. 1999; Xu et al. 2008).

As already reported, the hla and $h l b$ genes were highly decreased in expression after 60-min C-6-H incubation (spot vol. ratio $0.11 \pm 0.02$ ). These encode the major toxins $\alpha$-haemolysin ( $h l a)$ and $\beta$-haemolysin ( $h l b)$, which are membrane-damaging molecules, expressed in postexponential phase, and are important for spreading into new host tissues (Bhakdi and Tranum-Jensen 1991). The effect of C-6-H on hla expression was expected as earlier reports have shown that fatty acids (e.g. glycerol monolaurate (GML) were able to inhibit the expression of virulence determinants in S. aureus (Schlievert et al. 1992; Projan et al. 1994). Clarke et al. (2007) found that C-6-H is able to inhibit the expression of $\alpha$-haemolysin ( $h l a)$ and protein A (spa) at the transcriptional level. Since no change in RNAIII expression (agr, the main regulator of virulence 
factors) has been observed after the exposure to C-6-H or GML, it leads to the suggestion that the effect of C-6-H on the expression of virulence determinants is due to another regulatory system (Projan et al. 1994; Clarke et al. 2007). In contrast, Kenny et al. (2009) observed that the expression of hla and spa was up-regulated after exposure of MRSA252 to linoleic or oleic acid.

The expression of $s b i$ (IgG-binding protein) was negatively affected by C-6-H (spot vol. ratio 0.09 and 0.18 and after 10- and 60-min incubation, respectively). Sbi has an important role in adherence to host cells during the infective process and acts similarly to protein A (Zhang et al. 1998).

Effects of C-6-H on general intracellular processes

Microarray data revealed altered expression of genes involved in carotenoid biosynthesis. The genes $\operatorname{crtN}$ (squalene desaturase), crtM (squalene synthase), crt $Q$ (putative glycosyl transferase), crtP (4,4'-diaponeurosporene oxidase) and SA2352 (hypothetical protein) were increased in expression after incubation for $10 \mathrm{~min}$ with C-6-H (spot vol. ratio $3.7 \pm 1.7$ ). It has been reported that there is a direct correlation between carotenoid production and cell membrane fluidity (Chamberlain et al. 1991; Mishra et al. 2009). The carotenoids insert into the membrane and increase its rigidity, which could lead to its stabilization in response to C-6-H. Previous studies reported that long-chain unsaturated fatty acids could lead to an increase in membrane fluidity (Chamberlain et al. 1991). In the presence of the fatty acid C-6-H, the transcriptome data also showed an increase in expression of genes involved in fatty acid biosynthesis $(f a b D, f a b G$, acp $P$ ) after 60-min challenge conditions with $\mathrm{C}-6-\mathrm{H}$ (spot vol. ratio $2.1 \pm 0.1$ ) (Table S1). The synthesis of fatty acids is essential for membrane phospholipid formation and stability, suggesting that $S$. aureus responds to the potential loss of membrane integrity due to C-6-H by increasing the expression of genes involved in fatty acid biosynthesis.

Several genes involved in stress responses were affected in expression by C-6-H incubation. The katA gene encodes catalase and is increased in expression only after 10-min incubation with C-6-H (spot vol. ratio 5). It is important for $S$. aureus for neutralisation of $\mathrm{H}_{2} \mathrm{O}_{2}$, survival and nasal colonisation (Cosgrove et al. 2007).

The microarray data revealed that genes of the Clp family $(\operatorname{clp} C, \operatorname{clpB}$ and $\operatorname{clp} L$ ) were increased in expression in the presence of C-6-H (spot vol. ratio 2.4, 3.7 and 13.1, respectively). ClpC is a chaperone with ATPase activity, and together with $\mathrm{ClpB}$, it is highly induced during thermal stress with a function to degrade heatdamaged proteins, as well as an important role in biofilm

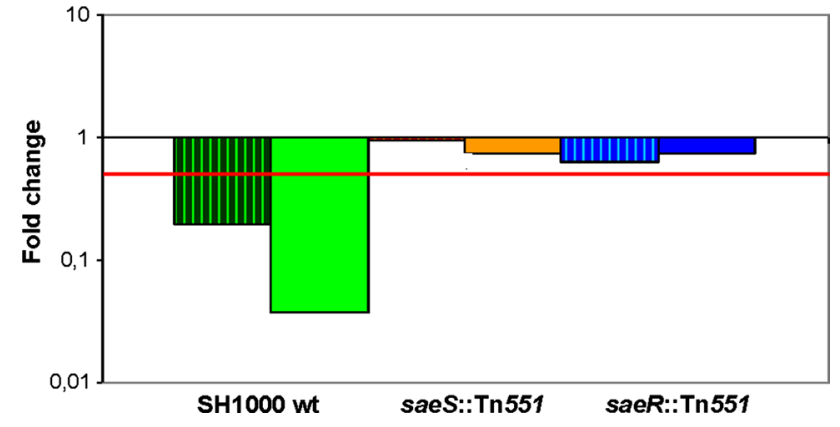

Fig. 4 Effect of C-6-H on hla expression in saeRS mutant strains. $S$. aureus SH1000 wt, SH1000 saeS: :Tn551 and SH1000 saeR::Tn551 were grown in $\mathrm{TSB}^{-\mathrm{Fe}}$ until $\mathrm{OD}_{600} 0.5 .8 \mu \mathrm{g} / \mathrm{ml} \mathrm{C}-6-\mathrm{H}$ was added to the cultures, and cells were incubated for 10 (striped bars) or 60 (filled bars) min. Total mRNA was isolated, and an qRT-PCR experiment was performed determining hla expression. Red line shows significant change of at least 0.5 -fold. The samples were measured in triplicate, and qRT-PCR experiment was carried out three times

formation (Becker et al. 2001; Frees et al. 2003). ClpB is required for growth at high temperature (Frees et al. 2003). ClpL is also an ATP-dependent proteinase and is important in the thermotolerance of $S$. aureus (Frees et al. 2003).

In response to $\mathrm{C}-6-\mathrm{H}$, there is an up-regulation of urease (ureA-G) expression (60-min incubation, spot vol. ratio $4 \pm 2$, Table S1). Urease is involved in hydrolysing urea into $\mathrm{NH}_{3}$ (ammonia) and $\mathrm{CO}_{2}$ (carbon dioxide) as a nitrogen source and acid resistance.

The transcription of dhoM (homoserine dehydrogenase), $\operatorname{thr} C$ (threonine synthetase) and $\operatorname{thr} B$ (homoserine kinase) was increased after incubation with C-6-H for $10 \mathrm{~min}$ (spot vol. ratio $7.5 \pm 3.5$ ) and for $60 \mathrm{~min}$ (spot vol. ratio $3.1 \pm 0.2$ ). All three proteins are important for amino acid synthesis such as serine, glycine or threonine. $\mathrm{ThrC}$ catalyses the last reaction of threonine synthesis from asparate.

\section{Real-time PCR (RT-PCR)}

The transcriptome data of selected genes were validated using RT-PCR (Table 3), whereas all samples were amplified in triplicate. The focus was on genes involved in virulence and stress response. The RT-PCR analysis showed that hla was 20-fold down-regulated after 60 -min incubation with C-6-H. For the genes $\operatorname{lrg} A, \operatorname{lrg} B$, katA, sarA, $s c e D$, cidA, lytS and butA, RT-PCR data also confirmed the microarray results, verifying the high impact of C-6-H on the expression of those genes. However, not all qRT-PCR data are in correlation with the effect of C-6-H observed in the microarray data. For $s p a, h p r T$, phoP, asp23, lytR and saeRS, no effect on expression due to $\mathrm{C}-6-\mathrm{H}$ was observed (Table 3). This demonstrates that multiple approaches 
Table 4 Growth phase associated changes in extracellular protein profile

\begin{tabular}{|c|c|c|c|c|}
\hline ORF N315 & Protein & Gene product & OD 1.0 versus $16 \mathrm{~h}$ & Spot ID \\
\hline SA0009 & SerS & Seryl-tRNA synthetase & 0.65 & 331 \\
\hline SA0091 & Plc & 1-Phosphatidylinositol phosphodiesterase precurosr & 2.29 & 563 \\
\hline SA0091 & Plc & 1-Phosphatidylinositol phosphodiesterase precurosr & 4.83 & 565 \\
\hline SA0091 & $\mathrm{Plc}$ & 1-Phosphatidylinositol phosphodiesterase precurosr & 38.19 & 571 \\
\hline SA0128 & SodM (SodA1) & Superoxide dismutase & 1.60 & 698 \\
\hline SA0131 & Pnp (DeoD1) & Purine nucleoside phosphorylase & 1.11 & 654 \\
\hline SA0131 & Pnp (DeoD1) & Purine nucleoside phosphorylase & 0.06 & 187 \\
\hline SA0162 & AldA & Aldehyde dehydrogenase homologue & 0.27 & 294 \\
\hline SA0182 & & Hypothetical protein, similar to indole-3-pyruvate decarboxylas & 1.12 & 280 \\
\hline SA0265 & LytM & Peptidoglycan hydrolase & 0.15 & 454 \\
\hline SA0265 & LytM & Peptidoglycan hydrolase & 0.13 & 460 \\
\hline SA0309 & Geh & Glycerol ester hydrolase & 2.29 & 170 \\
\hline SA0309 & Geh & Glycerol ester hydrolase & 3.08 & 171 \\
\hline SA0309 & Geh & Glycerol ester hydrolase & 2.84 & 172 \\
\hline SA0309 & Geh & Glycerol ester hydrolase & 1.81 & 175 \\
\hline SA0309 & Geh & Glycerol ester hydrolase & 4.03 & 177 \\
\hline SA0309 & Geh & Glycerol ester hydrolase & 9.64 & 199 \\
\hline SA0309 & Geh & Glycerol ester hydrolase & 3.28 & 212 \\
\hline SA0309 & Geh & Glycerol ester hydrolase & 1.76 & 224 \\
\hline SA0309 & Geh & Glycerol ester hydrolase & 21.07 & 229 \\
\hline SA0309 & Geh & Glycerol ester hydrolase & 5.23 & 272 \\
\hline SA0309 & Geh & Glycerol ester hydrolase & 1.81 & 282 \\
\hline SA0309 & Geh & Glycerol ester hydrolase & 0.83 & 421 \\
\hline SA0309 & Geh & Glycerol ester hydrolase & 2.75 & 433 \\
\hline SA0309 & Geh & Glycerol ester hydrolase & 0.57 & 439 \\
\hline SA0309 & Geh & Glycerol ester hydrolase & 3.00 & 443 \\
\hline SA0309 & Geh & Glycerol ester hydrolase & 1.20 & 451 \\
\hline SA0309 & Geh & Glycerol ester hydrolase & 1.90 & 176 \\
\hline SA0309 & Geh & Glycerol ester hydrolase & 1.17 & 217 \\
\hline SA0309 & Geh & Glycerol ester hydrolase & 3.97 & 221 \\
\hline SA0309 & Geh & Glycerol ester hydrolase & 0.68 & 238 \\
\hline SA0309 & Geh & Glycerol ester hydrolase & 2.99 & 248 \\
\hline SA0309 & Geh & Glycerol ester hydrolase & 1.32 & 259 \\
\hline SA0309 & Geh & Glycerol ester hydrolase & 1.97 & 293 \\
\hline SA0309 & Geh & Glycerol ester hydrolase & 3.40 & 418 \\
\hline SA0309 & Geh & Glycerol ester hydrolase & 8.89 & 424 \\
\hline SA0309 & Geh & Glycerol ester hydrolase & 5.58 & 435 \\
\hline SA0309 & Geh & Glycerol ester hydrolase & 1.15 & 436 \\
\hline SA0366 & $A h p C$ & Alkyl hydroperoxide reductase subunit $C$ & 3.04 & 712 \\
\hline SA0375 & GuaB & Inositol-monophosphate dehydrogenase & 0.34 & 308 \\
\hline SA0376 & GuaA & GMP synthase & 2.00 & 274 \\
\hline SA0382 & Set6 & Superantigen-like protein & 0.03 & 706 \\
\hline SA0482 & & Putative ATP: guanido phosphotransferase SA0482 & 0.76 & 366 \\
\hline SA0486 & GltX & Glutamyl-tRNA synthetase & 1.21 & 289 \\
\hline SA0486 & GltX & Glutamyl-tRNA synthetase & 0.41 & 302 \\
\hline SA0488 & CysS & Cysteinyl-tRNA synthetase & 0.64 & 309 \\
\hline SA0505 & FusA & Elongation factor $G$ & 0.14 & 162 \\
\hline SA0506 & Tuf & Elongation factor $\mathrm{Tu}$ & 0.69 & 371 \\
\hline
\end{tabular}


Table 4 continued

\begin{tabular}{|c|c|c|c|c|}
\hline ORF N315 & Protein & Gene product & OD 1.0 versus $16 \mathrm{~h}$ & Spot ID \\
\hline$\overline{\text { SA0506 }}$ & Tuf & Elongation factor $\mathrm{Tu}$ & 0.63 & 396 \\
\hline SA0544 & & Putative haem peroxidase & 0.21 & 618 \\
\hline SA0587 & & Lipoprotein, streptococcal adhesin PsaA homologue & 1.63 & 561 \\
\hline SA0587 & & Lipoprotein, streptococcal adhesin PsaA homologue & 0.22 & 610 \\
\hline SA0620 & & Secretory antigen SsaA homologue & 0.28 & 626 \\
\hline SA0674 & & Glycerol phosphate lipoteichoic acid synthase & 0.87 & 336 \\
\hline SA0674 & & Glycerol phosphate lipoteichoic acid synthase & 0.53 & 343 \\
\hline SA0674 & & Glycerol phosphate lipoteichoic acid synthase & 1.15 & 344 \\
\hline SA0674 & & Glycerol phosphate lipoteichoic acid synthase & 0.70 & 346 \\
\hline SA0674 & & Glycerol phosphate lipoteichoic acid synthase & 0.50 & 353 \\
\hline SA0686 & NrdE & Ribonucleotide-diphosphate reductase subunit alpha & 0.51 & 189 \\
\hline SA0719 & $\operatorname{TrxB}$ & Thioredoxin reductase & 1.82 & 508 \\
\hline SA0727 & Gap & Glyceraldehyde-3-phosphate dehydrogenase & 0.54 & 447 \\
\hline SA0728 & Pgk & Phosphoglycerate kinase & 0.57 & 409 \\
\hline SA0731 & Eno & Phosphopyruvate hydratase & 0.55 & 384 \\
\hline SA0732 & ClpP & ClpP & 1.07 & 729 \\
\hline SA0775 & & Hypothetical protein & 0.52 & 296 \\
\hline SA0787 & & IS1181 transposase & 0.37 & 242 \\
\hline SA0802 & & NADH dehydrogenase-like protein SA0802 & 0.94 & 411 \\
\hline SA0820 & GlpQ & Glycerophosphoryl diester phosphodiesterase & 2.31 & 569 \\
\hline SA0820 & GlpQ & Glycerophosphoryl diester phosphodiesterase & 1.72 & 570 \\
\hline SA0823 & Pgi & Glucose-6-phosphate isomerase & 1.10 & 378 \\
\hline SA0829 & & Hypothetical protein & 0.16 & 573 \\
\hline SA0831 & $\mathrm{Cdr}$ & Coenzyme A disulphide reductase & 2.08 & 349 \\
\hline SA0842 & $\mathrm{FabH}$ & FabH, 3-oxoacyl-(acyl carrier protein) synthase homologue & 1.04 & 489 \\
\hline SA0843 & $\mathrm{Fab}(\mathrm{FabF})$ & 3-oxoacyl-synthase & 0.94 & 362 \\
\hline SA0900 & SspB1 & Cysteine protease precursor SspB & 1.72 & 427 \\
\hline SA0900 & SspB1 & Cysteine protease precursor SspB & 1.25 & 432 \\
\hline SA0900 & SspB1 & Cysteine protease precursor SspB & 2.53 & 468 \\
\hline SA0900 & SspB1 & Cysteine protease precursor SspB & 1.51 & 825 \\
\hline SA0901 & SspA & V8 protease & 0.77 & 474 \\
\hline SA0901 & SspA & V8 protease & 1.26 & 478 \\
\hline SA0901 & SspA & V8 protease & 1.30 & 483 \\
\hline SA0901 & SspA & V8 protease & 1.73 & 486 \\
\hline SA0901 & SspA & V8 protease & 0.39 & 507 \\
\hline SA0901 & SspA & V8 protease & 1.47 & 511 \\
\hline SA0901 & SspA & V8 protease & 1.37 & 490 \\
\hline SA0904 & Atl & ATL autolysin transcription regulator & 0.28 & 163 \\
\hline SA0908 & & Hypothetical protein & 1.80 & 417 \\
\hline SA0908 & & Hypothetical protein & 1.90 & 419 \\
\hline SA0935 & PtsI & Phosphoenolpyruvate-protein phosphatase & 0.09 & 244 \\
\hline SA0939 & & Hypothetical protein & 0.12 & 676 \\
\hline SA0945 & $P d h C$ & Branched-chain alpha-keto acid dehydrogenase subunit E2 & 0.47 & 192 \\
\hline SA0946 & PdhD & Dihydrolipoamide dehydrogenase & 1.04 & 287 \\
\hline SA1007 & Hla & Alpha-haemolysin & 5.28 & 531 \\
\hline SA1007 & Hla & Alpha-haemolysin & 2.71 & 536 \\
\hline SA1007 & Hla & Alpha-haemolysin & 5.04 & 539 \\
\hline SA1007 & Hla & Alpha-haemolysin & 4.60 & 541 \\
\hline SA1007 & Hla & Alpha-haemolysin & 1.92 & 651 \\
\hline
\end{tabular}


Table 4 continued

\begin{tabular}{|c|c|c|c|c|}
\hline ORF N315 & Protein & Gene product & OD 1.0 versus $16 \mathrm{~h}$ & Spot ID \\
\hline SA1036 & IleS & Isoleucyl-tRNA synthetase & 0.41 & 132 \\
\hline SA1098 & CodY & Transcriptional repressor CodY & 2.87 & 617 \\
\hline SA1099 & RpsB & 30S ribosomal protein $\mathrm{S} 2$ & 0.55 & 514 \\
\hline SA1100 & Tsf & Elongation factor Ts & 2.23 & 459 \\
\hline SA1100 & Tsf & Elongation factor Ts & 1.58 & 470 \\
\hline SA1128 & $\operatorname{Rec} A$ & Recombinase A & 0.79 & 389 \\
\hline SA1150 & GlnA & Glutamine-ammonia ligase & 1.70 & 323 \\
\hline SA1170 & KatA & Catalase & 1.87 & 263 \\
\hline SA1177 & $T k t$ & Transketolase & 0.40 & 197 \\
\hline SA1177 & Tkt & Transketolase & 1.31 & 201 \\
\hline SA1177 & Tkt & Transketolase & 3.11 & 401 \\
\hline SA1533 & AckA & Acetate kinase homologue & 0.40 & 393 \\
\hline SA1184 & $\operatorname{CitB}(A c n A)$ & Aconitate hydratase & 0.23 & 128 \\
\hline SA1216 & PepF & Hypothetical protein, similar to oligoendopeptidase & 33.50 & 215 \\
\hline SA1283 & $\mathrm{Pbp} 2$ & PBP2 & 0.57 & 220 \\
\hline SA1308 & RpsA & $30 \mathrm{~S}$ ribosomal protein $\mathrm{S} 1$ & 0.43 & 363 \\
\hline SA1336 & & Glucose-6-phosphate 1-dehydrogenase & 1.50 & 250 \\
\hline SA1342 & Gnd & 6-Phosphogluconate dehydrogenase & 2.22 & 391 \\
\hline SA1342 & Gnd & 6-Phosphogluconate dehydrogenase & 2.20 & 400 \\
\hline SA1359 & Efp & Elongation factor $\mathrm{P}$ & 0.40 & 560 \\
\hline SA1409 & DnaK & Molecular chaperone DnaK & 0.69 & 226 \\
\hline SA1409 & DnaK & Molecular chaperone DnaK & 2.15 & 546 \\
\hline SA1499 & Tig & Trigger factor & 0.10 & 231 \\
\hline SA1520 & PykA & Pyruvate kinase & 0.68 & 203 \\
\hline SA1529 & & Metal-dependent hydrolase & 6.88 & 669 \\
\hline SA1553 & Fhs & Formate-tetrahydrofolate ligase & 2.57 & 273 \\
\hline SA1553 & Fhs & Formate-tetrahydrofolate ligase & 1.16 & 277 \\
\hline SA1579 & LeuS & Leucyl-tRNA synthetase & 2.68 & 143 \\
\hline SA1599 & Tal & Hypothetical protein, similar to transaldolase & 1.17 & 659 \\
\hline SA1609 & PckA & Phosphoenolpyruvate carboxykinase & 2.05 & 279 \\
\hline SA1627 & SplF & Serine protease SplE, putative & 2.93 & 667 \\
\hline SA1627 & $\mathrm{SplF}$ & Serine protease SplE, putative & 7.46 & 660 \\
\hline SA1627 & SplF & Serine protease SplE, putative & 7.88 & 670 \\
\hline SA1628 & SplD & Serine protease SplD & 4.68 & 666 \\
\hline SA1629 & SplC & Serine protease SplC & 4.43 & 656 \\
\hline SA1629 & SplC & Serine protease SplC & 1.41 & 657 \\
\hline SA1630 & SplB & Serine protease $S p l B$ & 6.64 & 646 \\
\hline SA1631 & SplA & Serine protease SplA & 4.55 & 642 \\
\hline SA1631 & SplA & Serine protease SplA & 2.01 & 647 \\
\hline SA1637 & LukD & Leukotoxin, LukD & 1.22 & 487 \\
\hline SA1653 & TRAP & Signal transduction protein TRAP & 6.36 & 914 \\
\hline SA1695 & AmpS & Aminopeptidase ampS & 1.34 & 397 \\
\hline SA1709 & & Ferritin & 0.32 & 910 \\
\hline SA1725 & SspB2 & Staphopain, cysteine proteinase & 1.76 & 725 \\
\hline SA1725 & SspB2 & Staphopain, cysteine proteinase & 6.01 & 754 \\
\hline SA1811 & $\mathrm{Hlb}$ & Beta-haemolsysin & 1.28 & 505 \\
\hline SA1811 & $\mathrm{Hlb}$ & Beta-haemolsysin & 1.02 & 509 \\
\hline SA1811 & $\mathrm{Hlb}$ & Beta-haemolsysin & 0.38 & 515 \\
\hline SA1811 & Hlb & Beta-haemolsysin & 5.31 & 519 \\
\hline
\end{tabular}


Table 4 continued

\begin{tabular}{|c|c|c|c|c|}
\hline ORF N315 & Protein & Gene product & OD 1.0 versus $16 \mathrm{~h}$ & Spot ID \\
\hline SA1811 & $\mathrm{Hlb}$ & Beta-haemolsysin & 2.31 & 520 \\
\hline SA1811 & $\mathrm{Hlb}$ & Beta-haemolsysin & 0.29 & 522 \\
\hline SA1811 & $\mathrm{Hlb}$ & Beta-haemolsysin & 0.65 & 574 \\
\hline SA1812 & & Uncharacterized leukocidin-like protein 1 precursor & 1.64 & 499 \\
\hline SA1812 & & Uncharacterized leukocidin-like protein 1 precursor & 2.19 & 500 \\
\hline SA1812 & & Uncharacterized leukocidin-like protein 1 precursor & 1.21 & 502 \\
\hline SA1813 & & Uncharacterized leukocidin-like protein 2 precursor & 0.72 & 494 \\
\hline SA182 & SodA (SodA2) & Superoxide dismutase SodA & 1.53 & 697 \\
\hline SA1836 & GroEL & Chaperonin GroEL & 0.37 & 267 \\
\hline SA1898 & & Hypothetical protein, similar to SceD precursor & 0.27 & 552 \\
\hline SA1905 & AtpD & F0F1 ATP synthase subunit beta & 0.28 & 383 \\
\hline SA1915 & GlyA & Serine hydroxymethyltransferase & 1.24 & 364 \\
\hline SA1915 & GlyA & Serine hydroxymethyltransferase & 0.90 & 367 \\
\hline SA1927 & $\mathrm{FbaA}$ & Fructose-bisphosphate aldolase & 0.61 & 530 \\
\hline SA1959 & GlmS & Glucosamine-fructose-6-phosphate transferase & 1.12 & 218 \\
\hline SA1984 & Asp23 & Alkaline shock protein 23 & 1.66 & 827 \\
\hline SA2003 & HysA & Hyaluronate lyase precursor & 0.30 & 156 \\
\hline SA2093 & SsaA & Secretory antigen precursor SsaA homologue & 0.09 & 592 \\
\hline SA2093 & SsaA & Secretory antigen precursor SsaA homologue & 0.10 & 593 \\
\hline SA2097 & & Hypothetical protein, similar to secretory antigen precursor SsaA & 0.24 & 860 \\
\hline SA2204 & GpmA & Phosphoglycerate mutase, pgm homologue & 3.01 & 583 \\
\hline SA2204 & GpmA & Phosphoglycerate mutase, pgm homologue & 1.36 & 585 \\
\hline SA2206 & Sbi & IgG-binding protein SBI & 0.29 & 387 \\
\hline SA2208 & $\mathrm{HlgC}$ & Gamma-haemolysin component $C$ & 3.73 & 535 \\
\hline SA2209 & $H \lg B$ & Gamma-haemolysin component $B$ & 2.47 & 497 \\
\hline SA2334 & MmvaS & 3-Hydroxy-3-methylglutaryl CoA synthase & 0.68 & 434 \\
\hline SA2336 & ClpL & ATP-dependent Clp proteinase chain clpL & 0.35 & 210 \\
\hline SA2356 & IsaA & Immunodominant antigen $\mathrm{A}$ & 0.23 & 616 \\
\hline SA2356 & IsaA & Immunodominant antigen $A$ & 0.22 & 635 \\
\hline SA2356 & IsaA & Immunodominant antigen $\mathrm{A}$ & 2.08 & 747 \\
\hline SA2356 & IsaA & Immunodominant antigen $\mathrm{A}$ & 1.43 & 822 \\
\hline SA2356 & IsaA & Immunodominant antigen $\mathrm{A}$ & 0.24 & 908 \\
\hline SA2430 & Aur & Zinc metalloproteinase aureolysin & 0.21 & 471 \\
\hline SA2430 & Aur & Zinc metalloproteinase aureolysin & 0.79 & 496 \\
\hline SA2437 & & Hypothetical protein, similar to autolysin precursor & 0.36 & 191 \\
\hline SA2437 & & Hypothetical protein, similar to autolysin precursor & 0.19 & 193 \\
\hline$S A 2437$ & & Hypothetical protein, similar to autolysin precursor & 0.16 & 195 \\
\hline SA2437 & & Hypothetical protein, similar to autolysin precursor & 0.11 & 200 \\
\hline SA2437 & & Hypothetical protein, similar to autolysin precursor & 0.88 & 223 \\
\hline SA2437 & & Hypothetical protein, similar to autolysin precursor & 1.11 & 235 \\
\hline SA2437 & & Hypothetical protein, similar to autolysin precursor & 1.15 & 236 \\
\hline SA2437 & & Hypothetical protein, similar to autolysin precursor & 0.10 & 245 \\
\hline SA2437 & & Hypothetical protein, similar to autolysin precursor & 0.78 & 269 \\
\hline$S A 2437$ & & Hypothetical protein, similar to autolysin precursor & 0.41 & 422 \\
\hline
\end{tabular}

Table of all identified protein spots from the extracellular fraction. Data for proteins with a spot vol. ratio of $\geq 2$ and $\leq 0.5$ are shown. All proteins had a significance level of 0.05 or less ( $T$ test $5 \%$ cut-off). Proteins highlighted in italics are significantly changed in the two phases of growth 


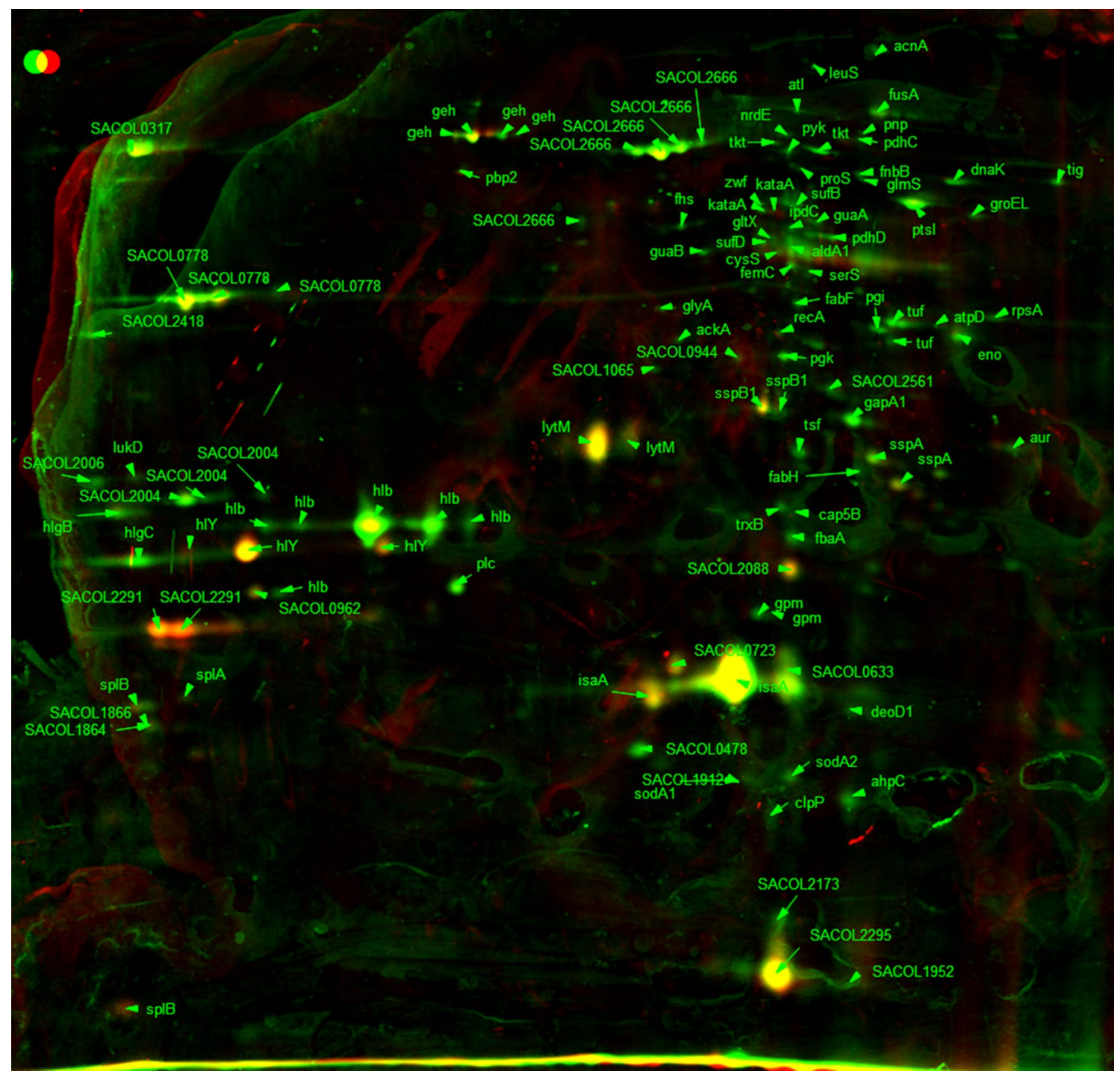

Fig. 5 2D gel image false-colour dual-channel of extracellular proteins in exponential phase with and without C-6-H. Merged 2D gel images of $S$. aureus SH1000 extracellular proteins from exponential

should be undertaken to verify changes in expression using these types of technologies.

Effect of C-6-H on the S. aureus regulatory system saeRS

The SaeRS response regulator is a key system that controls the expression of virulence determinants in S. aureus and is required for pathogenesis (Giraudo et al. 1994, 1997; Goerke et al. 2001, 2005; Harraghy et al. 2005). Interestingly, saeRS was down-regulated in response to C-6-H as shown by the transcriptome data. Further, many members of its regulon were decreased in expression as well, which suggests that signal transduction by SaeS may be altered as a direct, or indirect, consequence of C-6-H. It has been proposed earlier that fatty acids (such as GML or lauric phase treated with or without $10 \mu \mathrm{g} / \mathrm{ml} \mathrm{C-6-H}$. Control gel shown in green, treated samples shown in red and equal expression shown in yellow. Spots were identified via MALDI-TOF

acid) might affect the cell membrane and therefore disrupt important signalling mechanisms (Schlievert et al. 1992; Holland et al. 1994; Projan et al. 1994; Ruzin and Novick 1998; Vetter and Schlievert 2005). To investigate the role of the SaeRS system in the molecular mechanism of C-6-H, qRT-PCR experiments were performed. The transcription of hla in the presence of a sub-MIC of C-6-H using the saeS (saeS::Tn551) and saeR (saeR::Tn551) mutant strains in the SH1000 background was measured. In SH1000 wt, the expression of hla showed a reduction of over fourfold and 20-fold in the presence of C-6-H for 10 and $60 \mathrm{~min}$, respectively. The saeS mutant strain (saeS::Tn551) revealed no significant change in hla expression in the presence of C-6$\mathrm{H}$, at 10 or $60 \mathrm{~min}$ (Fig. 4). Similar results were observed using the saeR mutant strain (saeR::Tn551) which also 


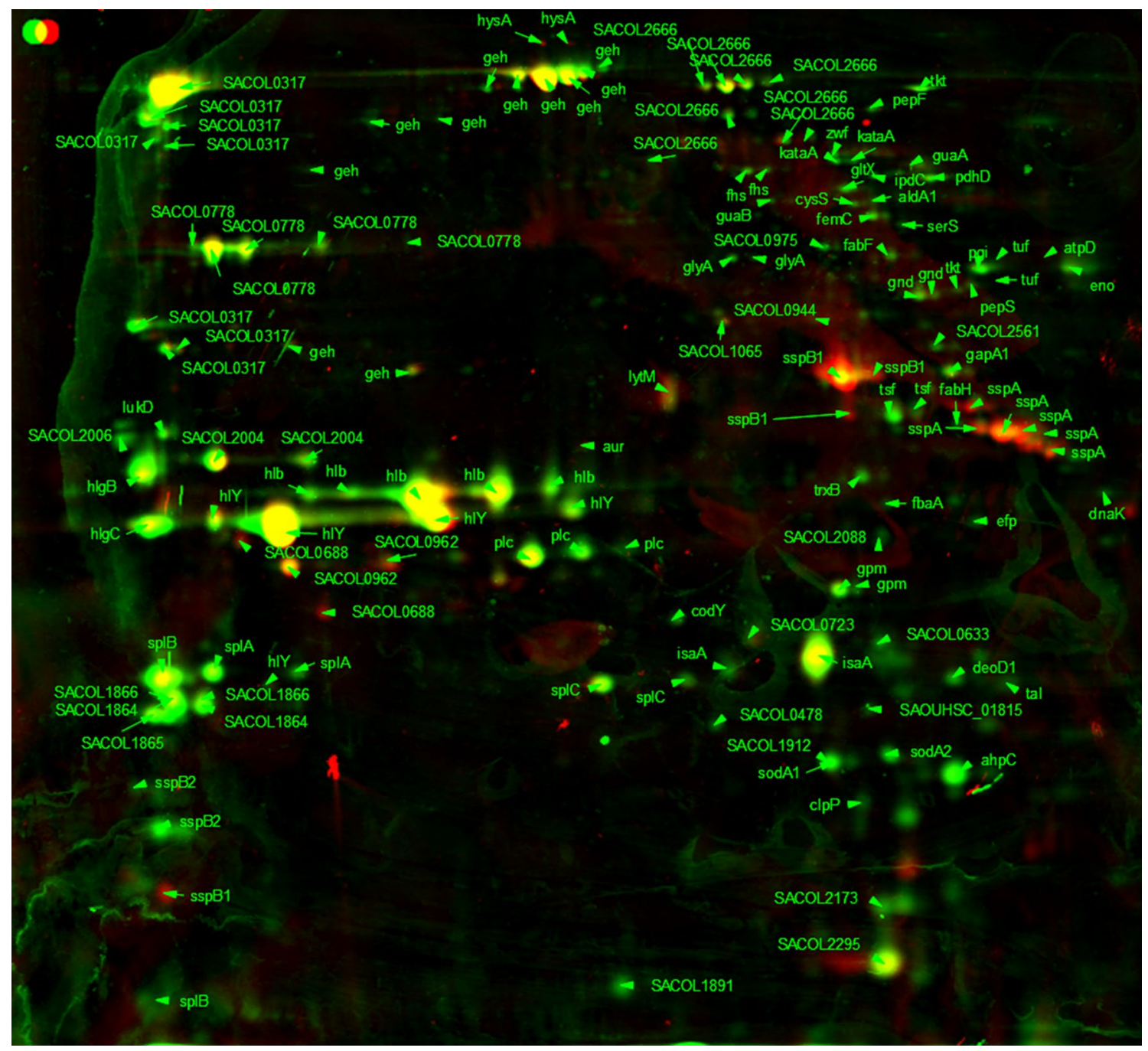

Fig. 6 2D gel image false-colour dual-channel of extracellular proteins in stationary phase with and without C-6-H. Merged 2D gel images of S. aureus SH1000 extracellular proteins from stationary phase treated with or without $10 \mu \mathrm{g} / \mathrm{ml} \mathrm{C-6-H.} \mathrm{Control} \mathrm{gel} \mathrm{shown} \mathrm{in}$ green, treated samples shown in red and equal expression shown in yellow. Spots were identified via MALDI-TOF showed no significant difference in hla expression in the presence of $\mathrm{C}-6-\mathrm{H}$, suggesting that the two-component system saeRS is implicated in the molecular mechanism of $\mathrm{C}-6-\mathrm{H}$. The molecular mechanism of $\mathrm{C}-6-\mathrm{H}$ in virulence determinant inhibition has not as yet been revealed, but an interference of the signal transduction system in $S$. aureus is a possible scenario.

\section{Effect of C-6-H on protein profiles}

Transcriptome analysis revealed a pleiotropic effect of $\mathrm{C}-6-\mathrm{H}$ on gene expression but whether this is translated into significant changes in protein levels and thus activities required a proteomic analysis. The effect of a sub-inhibitory concentration of C-6-H on the extracellular proteins of
S. aureus SH1000 was determined using the $2 \mathrm{D}$ gel technique (Table 4).

For the 2D gel analysis of extracellular proteins, culture supernatant was treated with $10 \%(\mathrm{w} / \mathrm{v})$ fresh TCA to precipitate all extracellular proteins. Figures 5 and 6 show the extracellular protein expression of $S$. aureus in early exponential phase $\left(\mathrm{OD}_{600} 1.0\right)$ and stationary phase $(16 \mathrm{~h}$ incubation). In total, 103 different proteins were identified in the extracellular protein fraction. Nine proteins showed an increase in the amount in stationary phase and 13 proteins showed a decrease in level compared with exponential phase (Table 5). As expected, virulence determinants that are involved in host defence evasion as well as invasion and tissue penetration showed an increased level in stationary phase. For example, $\alpha$-haemolysin (Hla) was over 4.5 -fold 
Table 5 Growth phase-dependent changes in extracellular protein profile

\begin{tabular}{|c|c|c|c|c|}
\hline ORF N315 & Protein & Gene product & OD 1.0 versus $16 \mathrm{~h}$ & Spot ID \\
\hline SA0265 & LytM & Peptidoglycan hydrolase & 0.15 & 454 \\
\hline SA0265 & LytM & Peptidoglycan hydrolase & 0.13 & 460 \\
\hline SA0309 & Geh & Glycerol ester hydrolase & 3.08 & 171 \\
\hline SA0309 & Geh & Glycerol ester hydrolase & 9.64 & 199 \\
\hline SA0309 & Geh & Glycerol ester hydrolase & 21.07 & 229 \\
\hline SA0309 & Geh & Glycerol ester hydrolase & 8.89 & 424 \\
\hline SA0375 & GuaB & Inositol-monophosphate dehydrogenase & 0.34 & 308 \\
\hline SA0393 & Set15 & Superantigen-like protein & 0.12 & 676 \\
\hline SA0505 & FusA & Elongation factor $\mathrm{G}$ & 0.14 & 162 \\
\hline SA0544 & & Putative haem peroxidase & 0.21 & 618 \\
\hline SA0935 & PtsI & Phosphoenolpyruvate-protein phosphatase & 0.09 & 244 \\
\hline SA0945 & $\mathrm{PdhC}$ & Branched-chain alpha-keto acid dehydrogenase subunit E2 & 0.47 & 192 \\
\hline SA1007 & Hla & Alpha-haemolysin & 5.28 & 531 \\
\hline SA1007 & Hla & Alpha-haemolysin & 4.60 & 541 \\
\hline SA1177 & Tkt & Transketolase & 0.40 & 197 \\
\hline SA1499 & Tig & Trigger factor & 0.10 & 231 \\
\hline SA1627 & SplF & Serine protease SplE, putative & 7.88 & 670 \\
\hline SA1628 & SplD & Serine protease SplD & 4.68 & 666 \\
\hline SA1630 & SplB & Serine protease SplB & 6.64 & 646 \\
\hline SA1725 & & Staphopain, cysteine proteinase & 6.01 & 754 \\
\hline SA1898 & & Hypothetical protein, similar to SceD precursor & 0.27 & 552 \\
\hline SA2093 & SsaA & Secretory antigen precursor SsaA homologue & 0.09 & 592 \\
\hline SA2093 & SsaA & Secretory antigen precursor SsaA homologue & 0.10 & 593 \\
\hline SA2204 & GpmA & Phosphoglycerate mutase, pgm homologue & 3.01 & 583 \\
\hline SA2208 & $\mathrm{H} \operatorname{lgC}$ & Gamma-haemolysin component C & 3.73 & 535 \\
\hline SA2209 & $\mathrm{HlgB}$ & Gamma-haemolysin component B & 2.47 & 497 \\
\hline SA2356 & IsaA & Immunodominant antigen $\mathrm{A}$ & 0.22 & 635 \\
\hline SA2437 & & Hypothetical protein, similar to autolysin precursor & 0.16 & 195 \\
\hline SA2437 & & Hypothetical protein, similar to autolysin precursor & 0.41 & 422 \\
\hline
\end{tabular}

Comparison of the pattern of extracellular protein expression in exponential phase $\left(\mathrm{OD}_{600} 1.0\right)$ and stationary phase of $S$. aureus. Data for proteins with a spot vol. ratio of $\geq 2$ and $\leq 0.5$ are shown. All genes had a significance level of 0.05 or less ( $T$ test $5 \%$ cut-off)

increased in level in stationary phase. Also, the glycerol ester hydrolase (Geh) main spots were increased ninefold to 21-fold (Table 4). Decreased protein levels in stationary phase were shown by several hypothetical proteins as well as the peptidoglycan hydrolase (LytM), immunodominant antigen $\mathrm{A}$ (IsaA) and secretory antigen (SsaA).

In early exponential phase $\left(\mathrm{OD}_{600} 1.0\right)$, the levels of 15 proteins were altered ( $\geq$ twofold) in the presence of C-6-H (Table 6). Thirteen proteins showed a reduced level and 2 proteins showed an increased level in the presence of C-6-H. In stationary phase (16 h), 18 proteins showed an altered level of expression in the presence of C-6-H. Thirteen proteins were reduced and 5 were increased in level (Table 6). In the presence of $\mathrm{C}-6-\mathrm{H}$, several virulence determinants were reduced in level in exponential phase. The $\beta$-haemolysin (Hlb) and $\gamma$-haemolysin (HlgC) showed fivefold and 2.5-fold reduction in exponential phase. At stationary phase, $\mathrm{Hlb}$ showed no alteration due to $\mathrm{C}-6-\mathrm{H}$, but $\mathrm{HlgC}$ and $\mathrm{HlgB}$ were 3.5 -fold reduced. The addition of C-6-H surprisingly showed no apparent effect on Hla level at either growth phase. The lipase (Geh) showed a growth phase-dependent response to $\mathrm{C}-6-\mathrm{H}$ as it was reduced in exponential phase but induced in stationary phase (Table 5).

One hundred and sixty-six cytoplasmic soluble proteins were identified in total and analysed by MALDI-TOF mass spectrometry. The differences in protein expression of exponential and stationary phase cell growth are shown in Table 7, and the effects of C-6-H are shown in Table 8 and Figs. 7, 8. The cytoplasmic proteins of $S$. aureus in early exponential phase $\left(\mathrm{OD}_{600} 1.0\right)$ and stationary phase (16 $\mathrm{h}$ incubation) were compared. Twenty proteins show 
Table 6 Effect of C-6-H on extracellular protein profile

\begin{tabular}{|c|c|c|c|c|c|c|}
\hline \multirow[t]{2}{*}{ ORF N315 } & \multirow[t]{2}{*}{ Protein } & \multirow[t]{2}{*}{ Gene product } & \multicolumn{4}{|c|}{ Expression $\mathrm{C} 6 \mathrm{H}$} \\
\hline & & & OD 1.0 & $16 \mathrm{~h}$ & Spot ID (OD 1.0) & Spot ID (16 h) \\
\hline SA0131 & Pnp (deoD1) & Purine nucleoside phosphorylase & - & 0.33 & & 654 \\
\hline SA0265 & LytM & Peptidoglycan hydrolase & 2.08 & - & 454 & \\
\hline SA0309 & Geh & Glycerol ester hydrolase & 0.23 & - & 421 & \\
\hline SA0309 & Geh & Glycerol ester hydrolase & - & 7.38 & & 212 \\
\hline SA0366 & AhpC & Alkyl hydroperoxide reductase subunit $\mathrm{C}$ & - & 0.18 & & 712 \\
\hline SA0505 & FusA & Elongation factor $\mathrm{G}$ & 0.20 & - & 162 & \\
\hline SA0506 & Tuf & Elongation factor $\mathrm{Tu}$ & 0.17 & - & 371 & \\
\hline SA0820 & GlpQ & Glycerophosphoryl diester phosphodiesterase & - & 2.88 & & 569 \\
\hline SA0843 & $\mathrm{Fab}(\mathrm{fabF})$ & 3-Oxoacyl-synthase & 0.10 & - & 362 & \\
\hline SA0900 & SspB1 & Cysteine protease precursor SspB & - & 7.57 & & 427 \\
\hline SA0900 & SspB1 & Cysteine protease precursor SspB & - & 5.78 & & 432 \\
\hline SA0901 & SspA & V8 protease & - & 13.24 & & 478 \\
\hline SA0901 & SspA & V8 protease & - & 9.44 & & 483 \\
\hline SA0901 & SspA & V8 protease & - & 5.19 & & 490 \\
\hline SA0935 & PtsI & Phosphoenolpyruvate-protein phosphatase & 0.18 & - & 244 & \\
\hline SA1100 & Tsf & Elongation factor Ts & 0.47 & - & 470 & \\
\hline SA1177 & Tkt & Transketolase & 0.25 & - & 201 & \\
\hline SA1184 & $\mathrm{CitB}(\operatorname{acn} \mathrm{A})$ & Aconitate hydratase & 0.13 & - & 128 & \\
\hline SA1409 & Dnak & Molecular chaperone DnaK & 0.19 & - & 226 & \\
\hline SA1627 & SplF & Serine protease SplE, putative & - & 0.36 & & 670 \\
\hline SA1630 & SplB & Serine protease SplB & - & 0.29 & & 646 \\
\hline SA1631 & SplA & Serine protease SplA & - & 0.27 & & 642 \\
\hline SA1631 & SplA & Serine protease SplA & - & 0.13 & & 647 \\
\hline SA1637 & LukD & Leukotoxin, LukD & - & 0.17 & & 487 \\
\hline SA1671 & & Hypothetical protein & - & 0.17 & & 698 \\
\hline SA1725 & SspB2 & Staphopain, cysteine proteinase & - & 0.19 & & 754 \\
\hline SA1811 & Hlb & Beta-hemolsysin & 0.17 & - & 505 & \\
\hline SA1811 & Hlb & Beta-hemolsysin & 0.19 & - & 509 & \\
\hline SA1811 & $\mathrm{Hlb}$ & Beta-hemolsysin & 0.16 & - & 519 & \\
\hline SA1812 & & Hypothetical protein & - & 0.44 & & 500 \\
\hline SA1813 & & Hypothetical protein & - & 0.07 & & 494 \\
\hline SA1959 & GlmS & Glucosamine-fructose-6-phosphate transferase & 0.05 & - & 218 & \\
\hline SA2093 & SsaA & Secretory antigen precursor SsaA homologue & 4.74 & - & 592 & \\
\hline SA2093 & SsaA & Secretory antigen precursor SsaA homologue & 6.24 & - & 593 & \\
\hline SA2204 & GpmA & Phosphoglycerate mutase, pgm homologue & 0.08 & - & 585 & \\
\hline SA2208 & $\mathrm{HlgC}$ & Gamma-haemolysin component C & 0.38 & - & 535 & \\
\hline SA2208 & $\mathrm{HlgC}$ & Gamma-haemolysin component C & - & 0.33 & & 535 \\
\hline SA2209 & HlgB & Gamma-haemolysin component B & - & 0.22 & & 497 \\
\hline SA2356 & IsaA & Immunodominant antigen A & - & 0.28 & & 616 \\
\hline SA2356 & IsaA & Immunodominant antigen A & - & 0.21 & & 635 \\
\hline SA2356 & IsaA & Immunodominant antigen A & - & 0.16 & & 747 \\
\hline SA2437 & & Hypothetical protein, similar to autolysin & - & 0.43 & & 223 \\
\hline SA2437 & & Hypothetical protein, similar to autolysin & - & 2.38 & & 236 \\
\hline
\end{tabular}

Comparison of extracellular protein production in exponential phase $\left(\mathrm{OD}_{600} 1.0\right)$ and stationary phase in the presence of sub-MIC C-6-H. Data for proteins with a spot vol. ratio of $\geq 2$ and $\leq 0.5$ are shown. All proteins had a significance level of 0.05 or less ( $T$ test $5 \%$ cut-off) 
Table 7 Growth phase-dependent changes in cytoplasmic protein profile

\begin{tabular}{|c|c|c|c|}
\hline ORF N315 & Protein & Gene product & OD 1.0 versus $16 \mathrm{~h}$ \\
\hline SA0149 & CapF & Capsular polysaccharide synthesis enzyme Cap5F & 2.18 \\
\hline SA0218 & MB & Formate acetyltransferase & 3.20 \\
\hline SA0224 & & Hypothetical protein, similar to 3-hydroxyacyl-CoA dehydrogenase & 28.28 \\
\hline SA0372 & & Hypothetical protein & 4.24 \\
\hline SA0506 & Tuf & Elongation factor $\mathrm{Tu}$ & 0.28 \\
\hline SA0506 & Tuf & Elongation factor $\mathrm{Tu}$ & 0.10 \\
\hline SA0513 & & Hypothetical protein & 0.35 \\
\hline SA0564 & $\operatorname{ArgS}$ & Arginyl-tRNA synthetase & 0.50 \\
\hline SA0707 & & Hypothetical protein & 3.06 \\
\hline SA0730 & Pgm & Phosphoglyceromutase & 0.30 \\
\hline SA0755 & & Organic hydroperoxide resistance protein-like & 2.34 \\
\hline SA0774 & & Hypothetical protein & 0.34 \\
\hline SA0793 & DltA & D-alanine-poly(phosphoribitol) ligase subunit 1 & 0.40 \\
\hline SA0842 & $\mathrm{FabH}$ & FabH, 3-oxoacyl-(acyl carrier protein) synthase homologue & 0.40 \\
\hline SA0843 & Fab & 3-oxoacyl-synthase & 0.44 \\
\hline SA0869 & FabI & Enoyl-(acyl carrier protein) reductase & 0.35 \\
\hline SA0959 & & GTP-binding elongation factor homologue & 0.32 \\
\hline SA1019 & & Hypothetical protein & 2.19 \\
\hline SA1045 & PyrAA & Carbamoyl phosphate synthase small subunit & 0.39 \\
\hline SA1073 & FabD & Malonyl CoA-acyl carrier protein transacylase & 0.48 \\
\hline SA1096 & ClpQ & ATP-dependent protease peptidase subunit & 2.46 \\
\hline SA1115 & RibC & Riboflavin kinase/FAD synthase ribC & 0.17 \\
\hline SA1224 & & $\mathrm{ABC}$ transporter (ATP-binding protein) homologue & 0.30 \\
\hline SA1224 & & $\mathrm{ABC}$ transporter (ATP-binding protein) homologue & 0.36 \\
\hline SA1307 & EngA & GTP-binding protein engA & 0.34 \\
\hline SA1309 & $\mathrm{Cmk}$ & Cytidylate kinase & 0.36 \\
\hline SA1343 & & Hypothetical protein, similar to tripeptidase & 7.03 \\
\hline SA1410 & GrpE & Heat shock protein GrpE & 0.46 \\
\hline SA1456 & AspS & Aspartyl-tRNA synthetase & 0.49 \\
\hline SA1456 & AspS & Aspartyl-tRNA synthetase & 0.41 \\
\hline SA1522 & AccA & Acetyl-CoA carboxylase carboxyltransferase subunit alpha & 0.45 \\
\hline SA1553 & Fhs & Formate-tetrahydrofolate ligase & 2.77 \\
\hline SA1553 & Fhs & Formate-tetrahydrofolate ligase & 2.13 \\
\hline SA1609 & PckA & Phosphoenolpyruvate carboxykinase & 6.03 \\
\hline SA1609 & PckA & Phosphoenolpyruvate carboxykinase & 3.67 \\
\hline SA1609 & PckA & Phosphoenolpyruvate carboxykinase & 6.65 \\
\hline SA1692 & & Hypothetical protein & 2.37 \\
\hline SA1709 & & Ferritin & 4.20 \\
\hline SA1724 & PurB & Adenylosuccinate lyase & 2.12 \\
\hline SA1840 & & Hypothetical protein & 2.02 \\
\hline SA1929 & PyrG & CTP synthase & 0.43 \\
\hline SA1936 & LuxS & S-ribosylhomocysteinase & 0.39 \\
\hline SA1984 & Asp23 & Alkaline shock protein 23 & 13.54 \\
\hline SA1984 & Asp23 & Alkaline shock protein 23 & 10.13 \\
\hline SA1984 & Asp23 & Alkaline shock protein 23 & 8.04 \\
\hline SA2098 & & Putative 2-hydroxyacid dehydrogenase SA2098 & 2.25 \\
\hline SA2125 & & Formimidoylglutamase & 2.12 \\
\hline SA2240 & & Hypothetical protein, similar to para-nitrobenzyl esterase chain A & 8.60 \\
\hline
\end{tabular}


Table 7 continued

\begin{tabular}{lllr}
\hline ORF N315 & Protein & Gene product & OD 1.0 versus 16 h \\
\hline SA2317 & & Hypothetical protein & 0.44 \\
SA2336 & ClpL & ATP-dependent Clp proteinase chain clpL & 2.57 \\
\hline
\end{tabular}

Comparison of the pattern of cytoplasmic protein expression in exponential phase $\left(\mathrm{OD}_{600} 1.0\right)$ and stationary phase of $S$. aureus. Proteins with a spot vol. ratio of $\geq 2$ and $\leq 0.5$ are shown. All proteins had a significant level of 0.05 or less ( $T$ test $5 \%$ cut-off)

Table 8 Effect of C-6-H on cytoplasmic protein profile
Comparison of cytoplasmic protein expression in exponential phase $\left(\mathrm{OD}_{600} 1.0\right)$ and stationary phase in the presence of sub-MIC C-6-H. Data for proteins with a spot vol. ratio of $\geq 2$ and $\leq 0.5$ are shown. All proteins had a significance level of 0.05 or less ( $T$ test $5 \%$ cut-off)

\begin{tabular}{|c|c|c|c|c|}
\hline \multirow[t]{2}{*}{ ORF N315 } & \multirow[t]{2}{*}{ Protein } & \multirow[t]{2}{*}{ Gene product } & \multicolumn{2}{|c|}{ Expression $\mathrm{C} 6 \mathrm{H}$} \\
\hline & & & $\mathrm{OD}_{600} 1.0$ & $16 \mathrm{~h}$ \\
\hline SA0165 & & Hypothetical protein, similar to alpha-helical coiled-coil & - & 0.15 \\
\hline SA0367 & & NADPH-dependent oxidoreductase & - & 2.13 \\
\hline SA0419 & MetB & Cystathionine gamma-synthase & 2.11 & - \\
\hline SA0506 & Tuf & Elongation factor $\mathrm{Tu}$ & 2.31 & - \\
\hline SA0506 & Tuf & Elongation factor $\mathrm{Tu}$ & - & 2.46 \\
\hline SA0513 & & Hypothetical protein & 0.48 & - \\
\hline SA0707 & & Hypothetical protein & 0.44 & - \\
\hline SA0758 & & Hypothetical protein, similar to thioredoxin & 0.50 & - \\
\hline SA0869 & FabI & Enoyl-(acyl carrier protein) reductase & 0.40 & - \\
\hline SA0884 & & Lipoate-protein ligase homologue & - & 2.09 \\
\hline SA1045 & PyrAA & Carbamoyl phosphate synthase small subunit & 0.35 & - \\
\hline SA1112 & InfB & Translation initiation factor IF-2 & - & 3.52 \\
\hline SA1115 & RibC & Riboflavin kinase/FAD synthase ribC & 0.21 & - \\
\hline SA1258 & & Hypothetical protein & 0.10 & - \\
\hline SA1522 & AccA & Acetyl-CoA carboxylase carboxyltransferase subunit alpha & 0.35 & - \\
\hline SA1868 & & Hypothetical protein & 0.23 & - \\
\hline SA1943 & & Hypothetical protein & 0.19 & - \\
\hline SA1959 & GlmS & Glucosamine-fructose-6-phosphate aminotransferase & - & 2.15 \\
\hline SA1959 & GlmS & Glucosamine-fructose-6-phosphate aminotransferase & - & 2.95 \\
\hline SA1959 & GlmS & Glucosamine-fructose-6-phosphate aminotransferase & 2.15 & - \\
\hline SA1984 & Asp23 & Alkaline shock protein 23 & - & 0.37 \\
\hline SA2084 & UreC & Urease subunit alpha & 14.42 & - \\
\hline SA2085 & UreE & Urease accessory protein UreE & 5.85 & - \\
\hline SA2085 & UreE & Urease accessory protein UreE & - & 3.28 \\
\hline SA2098 & & Putative 2-hydroxyacid dehydrogenase SA2098 & - & 2.09 \\
\hline SA2311 & & Putative NAD(P)H nitroreductase SA2311 & - & 2.62 \\
\hline SA2312 & Ddh & D-lactate dehydrogenase & 2.44 & - \\
\hline SA2336 & ClpL & ATP-dependent Clp proteinase chain clpL & - & 2.26 \\
\hline SA2336 & ClpL & ATP-dependent Clp proteinase chain clpL & - & 2.62 \\
\hline SA2400 & Mqo2 & Malate: quinone oxidoreductase & 0.44 & - \\
\hline SA2400 & Mqo2 & Malate: quinone oxidoreductase & 0.27 & - \\
\hline
\end{tabular}

an increase and 22 a decrease in level in stationary phase (Table 7), with a variety of predicted roles.

In early exponential phase, the expression levels of 17 proteins were altered ( $\geq 2$-fold) in the presence of C-6-H (Table 8). Eleven proteins showed a decrease and 6 an increase in level due to C-6-H. In stationary phase, 9 proteins were increased and 2 reduced in the presence of
C-6-H. The greatest induction by C-6-H was seen for UreC in exponential phase (14-fold). Also, UreE showed a fivefold induction in protein level (Table 8). The increased urease level is in accordance with the array data (Table S1). A variety of other metabolic proteins were also affected by C-6-H, which alludes to a generalised effect of the inhibitor on cellular processes. 


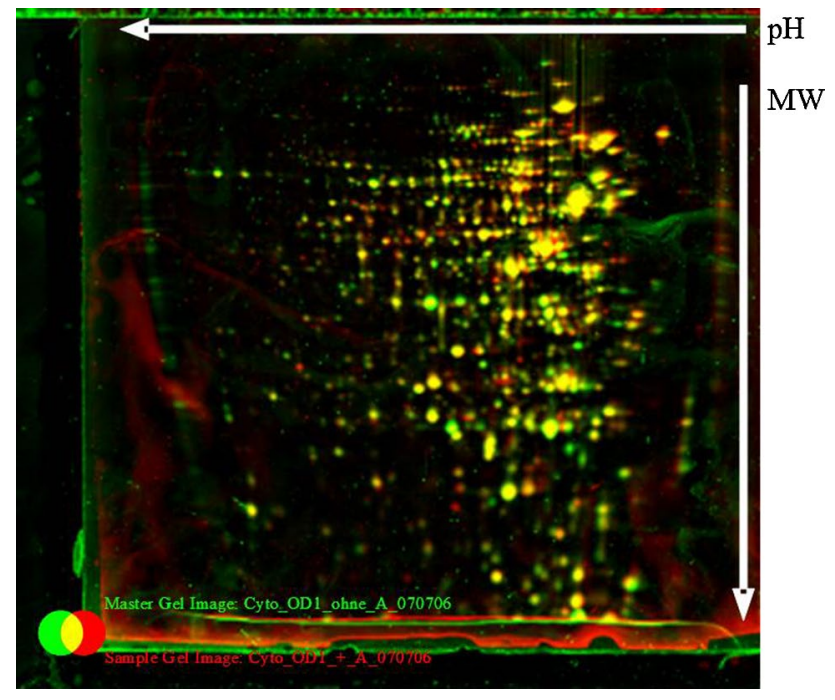

Fig. 7 Comparison of the cytoplasmic protein pattern of $S$. aureus SH1000, with or without C-6-H, in exponential phase. Original staining and false-colour dual-channel images of 2D gels of cytoplasmic proteins without C-6-H (green) and with C-6-H (red). Proteins $(200 \mu \mathrm{g})$ were isolated from the supernatant of SH1000 or grown in $\mathrm{TSB}^{-\mathrm{Fe}}$ medium to $\mathrm{OD}_{600} 0.5, \mathrm{C}-6-\mathrm{H}$ was then added, and cultures were further incubated until $\mathrm{OD}_{600}$ 1.0. Yellow protein spots represent equal amounts in both cultures, the green protein spots represent higher amounts in the culture without $\mathrm{C}-6-\mathrm{H}$, and protein spots that are red are present in higher amounts in the presence of $\mathrm{C}-6-\mathrm{H}$

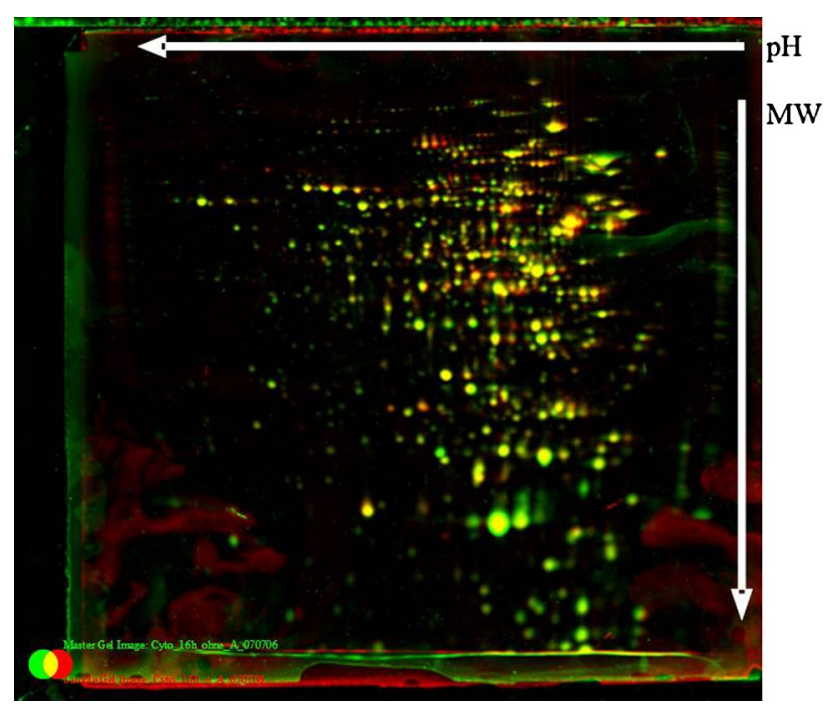

Fig. 8 Comparison of the cytoplasmic protein pattern of $S$. aureus $\mathrm{SH} 1000$, with or without C-6-H, in stationary phase. Original staining and false-colour dual-channel images of 2D gels of cytoplasmic proteins without C-6-H (green) and with C-6-H (red). Proteins (200 $\mu \mathrm{g})$ were isolated from the supernatant of $\mathrm{SH} 1000$ grown in $\mathrm{TSB}^{-\mathrm{Fe}}$ medium to $\mathrm{OD}_{600} 0.5$, C-6- $\mathrm{H}$ was then added, and cultures were further incubated for $16 \mathrm{~h}$ (stationary phase). Yellow protein spots represent equal amounts in both cultures, the green protein spots represent higher amounts in the culture without $\mathrm{C}-6-\mathrm{H}$, and protein spots that are red are present in higher amounts in the presence of C-6-H

\section{Conclusions}

There was broad (but not exact) correlation between the effects of $\mathrm{C}-6-\mathrm{H}$ on gene expression and protein level revealing a pleiotropic alteration in cellular physiology and virulence. Despite multiple changes in gene expression as a result of C-6-H exposure, no single resistance mechanism could be identified, which might suggest the contribution of several factors. Our data, however, support the hypothesis that the key regulator of virulence determinant production, SaeR, is affected by C-6-H and results in the reduced expression of several toxins. This would make sense as skin fatty acids are key markers for an environment in which $S$. aureus will colonise as part of the commensal flora. Expression of components able to disrupt the host will destroy this niche and potentiate other defences, thus placing the organism at risk.

Acknowledgments This work was funded by the European Union Project "StaphDynamics", the MRC (Ref. 78981) and the DFG (TRR34).

Open Access This article is distributed under the terms of the Creative Commons Attribution License which permits any use, distribution, and reproduction in any medium, provided the original author(s) and the source are credited.

\section{References}

Adhikari RP, Novick RP (2008) Regulatory organization of the staphylococcal sae locus. Microbiology 154:949-959

Baldassarri L, Bertuccini L, Ammendolia MG, Arciola CR, Montanaro L (2001) Effect of iron limitation on slime production by Staphylococcus aureus. Eur J Clin Microbiol Infect Dis 20:343-345

Bayles KW (2003) Are the molecular strategies that control apoptosis conserved in bacteria? Trends Microbiol 11:306-311

Bayles KW (2007) The biological role of death and lysis in biofilm development. Nat Rev 5:721-726

Becker P, Hufnagle W, Peters G, Herrmann M (2001) Detection of differential gene expression in biofilm-forming versus planktonic populations of Staphylococcus aureus using micro-representational-difference analysis. Appl Environ Microbiol 67:2958-2965

Berends ET, Horswill AR, Haste NM, Monestier M, Nizet V, von Kockritz-Blickwede M (2010) Nuclease expression by Staphylococcus aureus facilitates escape from neutrophil extracellular traps. J Innate Immun 2(6):576-586

Bernhardt J, Büttner K, Scharf C, Hecker M (1999) Dual channel imaging of two-dimensional electropherograms in Bacillus subtilis. Electrophoresis 20(11):2225-2240

Bhakdi S, Tranum-Jensen J (1991) Alpha-toxin of Staphylococcus aureus. Microbiol Rev 55:733-751

Brunskill EW, Bayles KW (1996) Identification of LytSR-regulated genes from Staphylococcus aureus. J Bacteriol 178(19): 5810-5812

Cartron ML, England SR, Chiriac AI, Josten M, Turner R, Rauter Y, Hurd A, Sahl H, Jones S, Foster SJ (2014) Bactericidal activity of the human skin fatty acid cis-6-hexadecanoic acid on Staphylococcus aureus. Antimicrob Agents Chemother 58(7):3599-3609 
Chamberlain NR, Mehrtens BG, Xiong Z, Kapral FA, Boardman JL, Rearick JI (1991) Correlation of carotenoid production, decreased membrane fluidity, and resistance to oleic acid killing in Staphylococcus aureus 18Z. Infect Immun 59:4332-4337

Chan PF, Foster SJ (1998) The role of environmental factors in the regulation of virulence-determinant expression in Staphylococcus aureus 8325-4. Microbiology 144(9):2469-2479

Clarke SR (2010) Phenol-soluble modulins of Staphylococcus aureus lure neutrophils into battle. Cell Host Microbe 7(6):423-424

Clarke SR, Foster SJ (2008) IsdA protects Staphylococcus aureus against the bactericidal protease activity of apolactoferrin. Infect Immun 76(4):1518-1526

Clarke SR, Wiltshire MD, Foster SJ (2004) IsdA of Staphylococcus aureus is a broad spectrum, iron-regulated adhesion. Mol Microbiol 51(5):1509-1519

Clarke SR, Mohamed R, Bian L, Routh AF, Kokai-Kun JF, Mond JJ, Tarkowski A, Foster SJ (2007) The Staphylococcus aureus surface protein IsdA mediates resistance to innate defenses of human skin. Cell Host Microbe 1:1-14

Cosgrove K, Coutts G, Jonsson IM, Tarkowski A, Kokai-Kun JF, Mond JJ, Foster SJ (2007) Catalase (KatA) and alkyl hydroperoxide reductase $(\mathrm{AhpC})$ have compensatory roles in peroxide stress resistance and are required for survival, persistence, and nasal colonization in Staphylococcus aureus. J Bacteriol 189:1025-1035

Duthie ES, Lorent LL (1952) Staphylococcal coagulase; mode of action and antigenicity. J Gen Microbiol 6(1-2):95-107

Eymann C, Dreisbach A, Albrecht D, Bernhardt J, Becher D, Gentner S, Tam LT, Büttner K, Buurman G, Scharf C, Venz S, Völker U, Hecker M (2004) A comprehensive proteome map of growing Bacillus subtilis cells. Proteomics 4(10):2849-2876

Frees D, Qazi SN, Hill PJ, Ingmer H (2003) Alternative roles of ClpX and ClpP in Staphylococcus aureus stress tolerance and virulence. Mol Microbiol 48:1565-1578

Geiger T, Goerke C, Mainiero M, Kraus D, Wolz C (2008) The virulence regulator Sae of Staphylococcus aureus: promoter activities and response to phagocytosis-related signals. J Bacteriol 190:3419-3428

Geiger T, Goerke C, Fritz M, Schäfer T, Ohlsen K, Liebeke M, Lalk M, Wolz C (2010) Role of the (p)ppGpp synthase RSH, a RelA/ SpoT homolog, in stringent response and virulence of Staphylococcus aureus. Infect Immun 78(5):1873-1883

Giesbrecht P, Kersten T, Maidhof H, Wecke J (1998) Staphylococcal cell wall: morphogenesis and fatal variations in the presence of penicillin. Microbiol Mol Biol Rev 62(4):1371-1414

Giraudo AT, Raspanti CG, Calzolari A, Nagel R (1994) Characterization of a Tn551-mutant of Staphylococcus aureus defective in the production of several exoproteins. J Microbiol 40(8):677-681

Giraudo AT, Cheung AL, Nagel R (1997) The sae locus of Staphylococcus aureus controls exoprotein synthesis at the transcriptional level. Arch Microbiol 168(1):53-58

Giraudo AT, Calzolari A, Cataldi AA, Bogni C, Nagel R (1999) The sae locus of Staphylococcus aureus encodes a two-component regulatory system. FESM 177(1):15-22

Goerke C, Fluckiger U, Steinhuber A, Zimmerli W, Wolz C (2001) Impact of the regulatory loci agr, sarA and sae of Staphylococcus aureus on the induction of alpha-toxin during device-related infection resolved by direct quantitative transcript analysis. Mol Microbiol 40:1439-1447

Goerke C, Esser S, Kummel M, Wolz C (2005) Staphylococcus aureus strain designation by agr and cap polymorphism typing and delineation of agr diversification by sequence analysis. Int $\mathbf{J}$ Med Microbiol 295(2):67-75

Groicher KH, Firek BA, Fujimoto DF, Bayles KW (2000) The Staphylococcus aureus $\operatorname{lrg} \mathrm{AB}$ operon modulates murein hydrolase activity and penicillin tolerance. J Bacteriol 182:1794-1801
Gründling A, Missiakas DM, Schneewind O (2006) Staphylococcus aureus mutants with increased lysostaphin resistance. J Bacteriol 188(17):6286-6297

Harraghy N, Kormanec J, Wolz C, Homerova D, Goerke C, Ohlsen K, Qazi S, Hill P, Herrmann M (2005) sae is essential for expression of the staphylococcal adhesins Eap and Emp. Microbiology 151(Pt 6): 1789-1800

Heinrichs JH, Gatlin LE, Kunsch C, Choi GH, Hanson MS (1999) Identification and characterization of SirA, an ironregulated protein from Staphylococcus aureus. J Bacteriol 181(5):1436-1443

Henze UU, Berger-Bachi B (1996) Penicillin-binding protein 4 overproduction increases beta-lactam resistance in Staphylococcus aureus. Antimicrob Agents Chemother 40(9):2121-2125

Holland KT, Taylor D, Farrell AM (1994) The effect of glycerol monolaurate on growth of, and production of toxic shock syndrome toxin-1 and lipase by, Staphylococcus aureus. J Antimicrob Chemother 33:41-55

Horsburgh MJ, Ingham E, Foster SJ (2001) In Staphylococcus aureus, fur is an interactive regulator with PerR, contributes to virulence, and is necessary for oxidative stress resistance through positive regulation of catalase and iron homeostasis. J Bacteriol 183(2):468-475

Kabara JJ, Swieczkowski DM, Conley AJ, Truant JP (1972) Fatty acids and derivatives as antimicrobial agents. Antimicrob Agents Chemother 2(1):23-28

Karakawa WW, Vann WF (1982) Capsular polysaccharides of Staphylococcus aureus. Semin Infect Dis 4:285-293

Kashiwagi K, Miyamoto S, Nukui E, Kobayashi H, Igarashi K (1993) Functions of potA and potD proteins in spermidinepreferential uptake system in Escherichia coli. J Biol Chem 268(26):19358-19363

Kenny JG, Ward D, Josefsson E, Jonsson IM, Hinds J, Rees HH, Lindsay JA, Tarkowski A, Horsburgh MJ (2009) The Staphylococcus aureus response to unsaturated long chain free fatty acids: survival mechanisms and virulence implications. PLoS One 4:e4344

Knapp HR, Melly MA (1986) Bactericidal effects of polyunsaturated fatty acids. J Infect Dis 154(1):84-94

Kobayashi M, Shimizu S (1999) Cobalt proteins. Eur J Biochem 261(1):1-9

Kohler T, Weidenmaier C, Peschel A (2009) Wall teichoic acid protects Staphylococcus aureus against antimicrobial fatty acids from human skin. J Bacteriol 191:4482-4484

Koprivnjak T, Mlakar V, Swanson L, Fournier B, Peschel A, Weiss JP (2006) Cation-induced transcriptional regulation of the dlt operon of Staphylococcus aureus. J Bacteriol 188(10):3622-3630

Kuroda M, Kuroda H, Oshima T, Takeuchi F, Mori H, Hiramatsu K (2003) Two-component system VraSR positively modulates the regulation of cell-wall biosynthesis pathway in Staphylococcus aureus. Mol Microbiol 49(3):807-821

Kusser WC, Ishiguro EE (1988) Effects of aminoglycosides and spectinomycin on the synthesis and release of lipopolysaccharide by Escherichia coli. Antimicrob Agents Chemother 32(8):1247-1250

MacMillan SV, Alexander DA, Culham DE, Kunte HJ, Marshall EV, Rochon D, Wood JM (1999) The ion coupling and organic substrate specificities of osmoregulatory transporter ProP in Escherichia coli. Biochim Biophys Acta 1420(1-2):30-44

McDevitt D, Francois P, Vaudaux P, Foster TJ (1994) Molecular characterization of the clumping factor (fibrinogen receptor) of Staphylococcus aureus. Mol Microbiol 11:237-248

McDevitt D, Nanavaty T, House-Pompeo K, Bell E, Turner N, McIntire L, Foster T, Hook M (1997) Characterization of the interaction between the Staphylococcus aureus clumping factor (ClfA) and fibrinogen. Eur J Biochem 247:416-424

Miller SJ, Aly R, Shinefield HR, Elias PM (1988) Antimicrobial activity of stratum corneum lipids from normal and essential fatty acid-deficient mice. Arch Dermatol 124:209-215 
Mishra NN, Liu GY, Yeaman MR, Yang SJ, Bayer AS (2009) Carotenoid induced alteration of cell membrane $(\mathrm{CM})$ fluidity impacts Staphylococcus aureus susceptibility to innate host defense peptides in vitro, abstr. C1-1362, p. 75. Abstract 49th Interscience conference Antimicrob. Agents Chemother. American Society for Microbiology, Washington, DC

Needham AJ, Kibart M, Crossley H, Ingham PW, Foster SJ (2004) Drosophila melanogaster as a model host for Staphylococcus aureus infection. Microbiology 150:2347-2355

Neuhaus FC, Baddiley J (2003) A continuum of anionic charge: structures and functions of D-alanyl-teichoic acids in gram-positive bacteria. Microbiol Mol Biol Rev 67(4):686-723

Niyousaba F, Ogawa H (2005) Protective roles of the skin against infection: implication of naturally occurring human antimicrobial agents beta-defensins, cathelicidin LL-37 and lysozyme. J Dermatol Sci 40(3):157-168

Nolan T, Hands RE, Bustin SA (2006) Quantification of mRNA using real-time RT-PCR. Nat Protoc 1(3):1559-1582

Novick RP, Jiang D (2003) The staphylococcus saeRS system coordinates environmental signal with agr quorum sensing. Microbiology 149(10):2709-2717

Ong PY, Ohtake T, Brandt C, Strickland I, Boguniewicz M, Ganz T, Gallo RL, Leung DY (2002) Endogenous antimicrobial peptides and skin infections in atopic dermatitis. N Engl J Med 347(15):1151-1160

O'Riordan K, Lee JC (2004) Staphylococcus aureus capsular polysaccharides. Clin Microbiol Rev 17:218-234

Padan E, Schuldiner S (1994) Molecular biology of $\mathrm{Na}^{+} / \mathrm{H}^{+}$antiporters: molecular devices that couple the $\mathrm{Na}^{+}$and $\mathrm{H}^{+}$circulation in cells. Biochim Biophys Acta 1187(2):206-210

Patton TG, Yang SJ, Bayles KW (2006) The role of proton motive force in expression of the Staphylococcus aureus cid and $1 \mathrm{rg}$ operons. Mol Microbiol 59:1395-1404

Paulus TJ, McGarry TJ, Shekelle PG, Rosenzweig S, Switzer RL (1982) Coordinate synthesis of the enzymes of pyrimidine biosynthesis in Bacillus subtilis. J Bacteriol 149(2):775-778

Peacock SJ, Foster TJ, Cameron BJ, Berendt AR (1999) Bacterial fibronectin-binding proteins and endothelial cell surface fibronectin mediate adherence of Staphylococcus aureus to resting human endothelial cells. Microbiology 145(Pt 12):3477-3486

Peacock SJ, de Silva I, Lowy FD (2001) What determines nasal carriage of Staphylococcus aureus? Trends Microbiol 9(12):605-610

Peschel A (2002) How do bacteria resist human antimicrobial peptides? Trends Microbiol 10(4):179-186

Pohl K, Francois P, Stenz L, Schlink L, Geiger T, Herbert S, Goerke C, Schrenzel J, Wolz C (2009) CodY in Staphylococcus aureus: a regulatory link between metabolism and virulence gene expression. J Bacteriol 191(9):2953-2963

Projan SJ, Brown-Skrobot S, Schlievert PM, Vandenesch F, Novick RP (1994) Glycerol monolaurate inhibits the production of $\beta$-lactamase, toxic shock syndrome toxin-1, and other staphylococcal exoproteins by interfering with signal transduction. J Bacteriol 176:4204-4209

Proksch E, Brandner JM, Jensen JM (2008) The skin: an indispensable barrier. Exp Dermatol 17(12):1063-1072

Ramadurai L, Lockwood KJ, Nadakavukaren MJ, Jayaswal RK (1999) Characterization of a chromosomally encoded glycylglycine endopeptidase of Staphylococcus aureus. Microbiology 145(Pt 4):801-808

Rice KC, Firek BA, Nelson JB, Yang SJ, Patton TG, Bayles KW (2003) The Staphylococcus aureus cidAB operon: evaluation of its role in regulation of murein hydrolase activity and penicillin tolerance. J Bacteriol 185:2635-2643

Ruzin A, Novick RP (1998) Glycerol monolaurate inhibits induction of vancomycin resistance in Enterococcus faecalis. J Bacteriol 180:182-185
Schlievert PM, Deringer JR, Kim MH, Projan SJ, Novick RP (1992) Effect of glycerol monolaurate on bacterial growth and toxin production. Antimicrob Agents Chemother 36:621-626

Sebulsky MT, Hohnstein D, Hunter MD, Heinrichs DE (2000) Identification and characterization of a membrane permease involved in iron-hydroxamate transport in Staphylococcus aureus. J Bacteriol 182(16):4394-4400

Sebulsky MT, Shilton BH, Speziali CD, Heinrichs DE (2003) The role of FhuD2 in iron(III)-hydroxamate transport in Staphylococcus aureus demonstration that FhuD2 binds iron(III)-hydroxamates but with minimal conformational change and implication of mutations on transport. J Biol Chem 278(50):49890-49900

Sharma-Kuinkel BK, Mann EE, Ahn JS, Kuechenmeister LJ, Dunman PM, Bayles KW (2009) The Staphylococcus aureus LytSR twocomponent regulatory system affects biofilm formation. J Bacteriol 191(15):4767-4775

Shin SY, Bajpai VK, Kim HR, Kang SC (2007) Antibacterial activity of bioconverted eicosapentaenoic (EPA) and docosahexaenoic acid (DHA) against foodborne pathogenic bacteria. Int J Food Microbiol 113(2):233-236

Srivatsan A, Wang JD (2008) Control of bacterial transcription, translation and replication by (p)ppGpp. Curr Opin Microbiol 11:100-105

Takigawa H, Nakagawa H, Kuzukawa M, Mori H, Imokawa G (2005) Deficient production of hexadecanoic acid in the skin is associated in part with the vulnerability of atopic dermatitis patients to colonization by Staphylococcus aureus. Dermatology 211:240-248

Turnbough CL Jr, Switzer RL (2008) Regulation of pyrimidine biosynthetic gene expression in bacteria: repression without repressors. Microbiol Mol Biol Rev 72(2):266-300

Turner RJ, Lu Y, Switzer RL (1994) Regulation of the Bacillus subtilis pyrimidine biosynthetic (pyr) gene cluster by an autogenous transcriptional attenuation mechanism. $\mathrm{J}$ Bacteriol 176(12):3708-3722

Vetter SM, Schlievert PM (2005) Glycerol monolaurate inhibits virulence factor production in Bacillus anthracis. Antimicrob Agents Chemother 49:1302-1305

Watts A, Ke D, Wang Q, Pillay A, Nicholson-Weller A, Lee JC (2005) Staphylococcus aureus strains that express serotype 5 or serotype 8 capsular polysaccharides differ in virulence. Infect Immun 73:3502-3511

Weidenmaier C, Peschel A, Kempf VA, Lucindo N, Yeaman MR, Bayer AS (2005) DltABCD- and MprF-mediated cell envelope modifications of Staphylococcus aureus confer resistance to platelet microbicidal proteins and contribute to virulence in a rabbit endocarditis model. Infect Immun 73(12):8033-8038

Wille JJ, Kydonieus A (2003) Palmitoleic acid isomer (C16:1 $\Delta 6)$ in human skin sebum is effective against gram-positive bacteria. Skin Pharmacol Appl Skin Physiol 16:176-187

Wolf C, Hochgräfe F, Kusch H, Albrecht D, Hecker M, Engelmann S (2008) Proteomic analysis of antioxidant strategies of Staphylococcus aureus: diverse responses to different oxidants. Proteomics 8(15):3139-3153

Wolz C, Geiger T, Goerke C (2010) The synthesis and function of the alarmone (p)ppGpp in firmicutes. Int J Med Microbiol 300:142-147

Xu CP, Boks NP, de Vries J, Kaper HJ, Norde W, Busscher HJ, van der Mei HC (2008) Staphylococcus aureus-fibronectin interactions with and without fibronectin-binding proteins and their role in adhesion and desorption. Appl Environ Microbiol 74:7522-7528

Zhang L, Jacobsson K, Vasi J, Lindberg M, Frykberg L (1998) A second IgG-binding protein in Staphylococcus aureus. Microbiology (Reading, England) 144(Pt 4):985-991 